\title{
First record of the dynamics of domoic acid producing Pseudo-nitzschia spp. in Indonesian waters as a function of environmental variability
}

\author{
Sem Likumahua ${ }^{\mathrm{a}, \mathrm{b}, *}$, M. Karin de Boer ${ }^{\mathrm{a}, \mathrm{c}}$, Bernd Krock ${ }^{\mathrm{d}}$, Tomas Nieuwenhuizen ${ }^{\mathrm{a}}$, \\ Willem M. Tatipatta ${ }^{\mathrm{b}}$, Salomy Hehakaya ${ }^{\mathrm{b}}$, La Imu ${ }^{\mathrm{b}}$, Malik S. Abdul ${ }^{\mathrm{b}}$, Eduard Moniharapon ${ }^{\mathrm{b}}$, \\ Anita G.J. Buma ${ }^{a}$ \\ ${ }^{a}$ Department of Ocean Ecosystems, Energy and Sustainability Research Institute Groningen, Faculty of Science and Engineering, University of Groningen, Nijenborgh 7, \\ 9747AG Groningen, the Netherlands \\ ${ }^{\mathrm{b}}$ Centre for Deep Sea Research-LIPI, Jl. Y. Syaranamual Guru-guru-Poka, 97233 Ambon, Indonesia \\ ${ }^{\mathrm{c}}$ Beta Science Shop, Faculty of Science and Engineering, University of Groningen, Nijenborgh 6, 9747AG Groningen, the Netherlands \\ ${ }^{\mathrm{d}}$ Alfred Wegener Institute, Helmholtz Centre for Polar and Marine Research, Am Handelshafen 12, 27570 Bremerhaven, Germany
}

\section{A R T I C L E I N F O}

\section{Keywords:}

Harmful algal blooms (HABs)

Neurotoxin

Ambon Bay

Pseudo-nitzschia spp

\begin{abstract}
A B S T R A C T
Within the past few decades, harmful algal blooms (HABs) have occurred frequently in Indonesian waters, resulting in environmental degradation, economic loss and human health problems. So far, HAB related studies mainly addressed ecological traits and species distribution, yet toxin measurements were virtually absent for Indonesian waters. The aim of the present study was to explore variability of the potentially toxic marine diatom genus Pseudo-nitzschia, as well as its neurotoxin domoic acid as a function of environmental conditions in Ambon Bay, eastern Indonesia. Weekly phytoplankton samples, oceanographic (CTD, nutrients) and meteorological (precipitation, wind) parameters were analyzed at 5 stations in the bay during the dry and wet seasons of 2018. Liquid chromatography - tandem mass spectrometry (LC-MS/MS) was used to detect particulate DA (pDA). Vegetative cells of Pseudo-nitzschia spp. and pDA were found in $98.6 \%$ and $51.4 \%$ of the samples, respectively. pDA levels were low, yet detected throughout the campaign, implying that Ambon Bay might potentially be subject to amnesic shellfish poisoning. The highest levels of both Pseudo-nitzschia spp. cell abundance and pDA were found in the wet season, showing a strong positive correlation between both parameters, compared to the dry season, $(r=0.87$ and $r=0.66$ ( $p<0.01$ ), respectively). Statistical analyses revealed that temperature and mixed layer depth positively correlated with Pseudo-nitzschia spp. and pDA during the dry season, while ammonium showed positive correlations in both seasons. This study represents the first successful investigation of the presence and variability of Pseudo-nitzschia spp. and its neurotoxin DA in Indonesian waters.
\end{abstract}

\section{Introduction}

Pseudo-nitzschia, a pennate and chain forming microalga is a cosmopolitan diatom genus that can cause harmful algal blooms (HABs) around the world (Trainer et al., 2000; Pan et al., 2001; Bates and Trainer, 2006). Some species of this genus produce a potent neurotoxin, known as domoic acid (DA). This toxin can be transferred via the food web, eventually causing amnesic shellfish poisoning (ASP) in humans due to the consumption of contaminated shellfish (Bates et al., 1998; Scholin et al., 2000; Bejarano et al., 2008; Mafra Jr. et al., 2010; Zabaglo et al., 2016). Human illness and fatalities due to DA outbreaks were first recorded in Canada in 1987, revealing symptoms such as gastrointestinal distress, confusion, disorientation, memory loss, coma and death (Bates et al., 1989; Lefebvre and Robertson, 2010). DA accumulated in filter feeders can also be fatal to higher marine trophic levels, such as mammals, leading to mortalities of sea lions and whales (Scholin et al., 2000; reviewed by Bejarano et al., 2008; Fire et al., 2010). The total number of described Pseudo-nitzschia species in the 2010s was 37 of which 12 were thought to be capable of producing DA (Trainer et al., 2010; reviewed by Trainer et al., 2012). This number recently increased to 52 species, of which 26 are capable of producing DA (Bates et al., 2018).

Environmental properties that promote the proliferation of Pseudonitzschia are very complex and vary between regions and seasons

\footnotetext{
*Corresponding author at: Department of Ocean Ecosystems, Energy and Sustainability Research Institute Groningen, Faculty of Science and Engineering, University of Groningen, Nijenborgh 7, 9747AG Groningen, the Netherlands.

E-mail address: s.likumahua@rug.nl (S. Likumahua).
} 
(Trainer et al., 2012; Umhau et al., 2018). This complexity and ambiguous causative factors may be related to natural climate variability (Sekula-Wood et al., 2011). Yet, in some cases, Pseudo-nitzschia was found to be correlated with nutrient availability. For example, cold upwelled and nutrient-rich waters were associated with Pseudo-nitzschia blooms in Californian coastal waters (Anderson et al., 2006; Schnetzer et al., 2007; Sekula-Wood et al., 2011). Eutrophic waters carrying high levels of nitrate derived from local groundwater favoured Pseudo-nitzschia to form blooms in the northern Gulf of Mexico (Macintyre et al., 2011).

Regardless of the complexity of the blooms and environmental properties, some factors are likely to be associated with cell specific toxin production. Phosphate and silicate limitation enhanced DA production in Pseudo-nitzschia species such as $P$. australis, P.pungens and $P$. fraudulenta (Lelong et al., 2012; Lema et al., 2017). Other factors that might regulate cell specific DA production were found to be $\mathrm{pH}, \mathrm{CO}_{2}$, irradiance, salinity, bacteria and temperature (Macintyre et al., 2011; Lelong et al., 2012; Zhu et al., 2017). Rue and Bruland (2001) found that Pseudo-nitzschia produces DA to bind trace metals in order to increase micronutrient availability (iron) or to reduce intracellular harmful copper. DA was found to accumulate in copepods (Leandro et al., 2010; Tammilehto et al., 2012), indicating grazing on Pseudonitzschia cells. Tammilehto et al. (2015) found that Pseudo-nitzschia seriata toxicity increased in the presence of grazers such as copepods, implying that zooplankton may trigger cell specific DA production.

In Indonesian waters, $\mathrm{HAB}$ outbreaks and their impacts on marine environments and human wellbeing have been observed since the early 1970s. However, due to a lack of experts, knowledge and awareness of HABs, studies in the country so far focused mainly on general species abundance (Sidharta, 2005). Indonesia has been suffering from paralytic shellfish poisoning (PSP) events caused by Pyrodinium bahamense var. compressum, which were associated with 427 cases of human illness and 17 deaths (Aditya et al., 2013; Azanza and Taylor, 2001). Other phytoplankton blooms were reported in the country coinciding with massive fish kill events due to dissolved oxygen depletion (Thoha et al., 2007; Wouthuyzen et al., 2007). To our knowledge, no particular studies addressed Pseudo-nitzschia spp. and its neurotoxin DA in Indonesian waters, including the eastern part of the country.

Ambon Bay is a semi-enclosed eutrophic bay in eastern Indonesia (Fig. 1), where proliferations of HAB species have frequently been observed. Human illness and fatalities were reported in the surrounding areas due to frequent occurrences of high densities of the toxic dinoflagellate Pyrodinium bahamense var. compressum (Likumahua, 2013). Phytoplankton monitoring is conducted in the bay since 2008 revealing other potentially toxic genera, such as Alexandrium, Gymnodinium, Dinophysis, and Pseudo-nitzschia, which was formerly determined as Nitzschia spp (data not published). However, the monitoring program was only focused on the abundance and distribution of phytoplankton with particular attention to dinoflagellates, nor did it include associated toxin analyses.

Given the complete lack of information on Pseudo-nitzschia occurrences and potential DA impacts in eastern Indonesian waters, the present study first of all addressed the possible presence and variability of DA producing Pseudo-nitzschia in Ambon Bay. Secondly, environmental factors that might regulate the variability of Pseudo-nitzschia and DA concentrations were investigated. To this end, a seven-months field campaign was executed in the bay, encompassing both the dry and the wet season, during which weather (wind, precipitation) and physicochemical water column properties (mixed layer depth, stratification, temperature, salinity, irradiance attenuation, nutrients) as well as phytoplankton composition and toxins were analysed.

\section{Materials and methods}

\subsection{Study area and stations}

Ambon Island $\left(3^{\circ} 38^{\prime} 17^{\prime \prime} \mathrm{S}\right.$ and $128^{\circ} 07^{\prime} 02^{\prime \prime} \mathrm{E}$ ) (Fig. 1) is located in Maluku Province, eastern Indonesia, which is resided by roughly 450,000 people. The island has a semi-enclosed estuary, known as Ambon Bay, which opens to the Banda Sea. A narrow and shallow sill (Fig. 2) divides the bay into two parts (Inner and Outer bay), which restricts water circulation and limits the flushing process to the open ocean (Banda Sea). The area has a tropical climate with high rainfall during the wet season, which is associated with the southeast monsoon occurring from March to September. The dry season is associated with the northwest monsoon between October and March, and it is characterized by relatively low precipitation and increased air temperature.

Four sampling stations (B, C, D, and E) were chosen in the inner part of the bay whereas a fifth station (A), with higher oceanic water influence, was set up in the outer bay (Fig. 1). Stations C and D are permanent stations, which have been monitored by the Center for Deep Sea Research Institute (LIPI) since 2008. Those stations are characterized by nearby dense mangrove vegetation and some small river outflows. Two blooms of toxic dinoflagellates had been recorded before at those stations during the wet season (Likumahua, 2013). Stations E and $\mathrm{B}$ were chosen close to moderately sized river outflows, which flush massive agricultural waste water into the inner bay during the wet season. These stations had experienced an extensive dinoflagellate bloom during the dry season in March 2013 (data unpublished). Some fish farms are located in the inner bay, close to stations C, D and E. At the LIPI research institute (Fig. 1), a weather station was installed to continuously measure precipitation, air temperature, wind and humidity. Daily average precipitation and wind speed were calculated and calibrated with the data obtained from the local Meteorological and Climate Bureau.

\subsection{Field sampling}

The five stations were sampled weekly throughout the dry and wet season, between January and July 2018. During the alleged phytoplankton bloom periods, both in the peak of dry (February-March) and wet (June-July) season, samples were collected twice a week. The period between end of March and mid- May was considered as the transition phase from the dry to wet season. Irradiance attenuation was measured using a LiCor Li1400 light meter, at 1, 2, 4, 6, 8, 10, 12, 16 and 20 (m depth). At each station, a Compact Alec CTD Model ASTD 687 was deployed to measure temperature, salinity, turbidity, density, and chlorophyll-a fluorescence.

A 3.5L Nansen bottle was used to collect water samples for nutrient analysis at 2 and $20 \mathrm{~m}$ depth, which represented the water above and below the thermocline. Since the water in the Inner bay is often turbid, the water samples were pre-filtered on board through a $20 \mu \mathrm{m}$ filter mesh to eliminate large plankton, other organic materials and sediment particles. The water samples were then transferred to $600 \mathrm{~mL}$ bottles and placed in a dark insulation box, containing seawater at ambient temperature. The bottles were pre-cleaned several times using distilled water and rinsed with double distilled water $\left(\mathrm{ddH}_{2} \mathrm{O}\right)$ prior to sampling.

At each station, a Hydro-bios plankton net with $40 \mathrm{~cm}$ diameter, $100 \mathrm{~cm}$ length, and $20 \mu \mathrm{m}$ mesh size was deployed twice vertically to collect plankton samples from $0-20 \mathrm{~m}$ depth, with total pulling time ranging between 60 and $70 \mathrm{~s}$, following the manufacturer's guidelines. The difference of approximately $10 \mathrm{~s}$ pulling speed (between $0.33 \mathrm{~m} / \mathrm{s}$ and $0.29 \mathrm{~m} / \mathrm{s}$ ) potentially caused variability of sampled volumes, which was calculated to be less than $12 \%$. This net tow method has been used to reveal a semi-quantitative comparison of cell abundances and particulate toxin concentrations as described by Fabro et al. (2016) and Almandoz et al. (2017). Plankton samples were transferred to $500 \mathrm{~mL}$ bottles and kept in the dark at ambient temperature in the insulation 


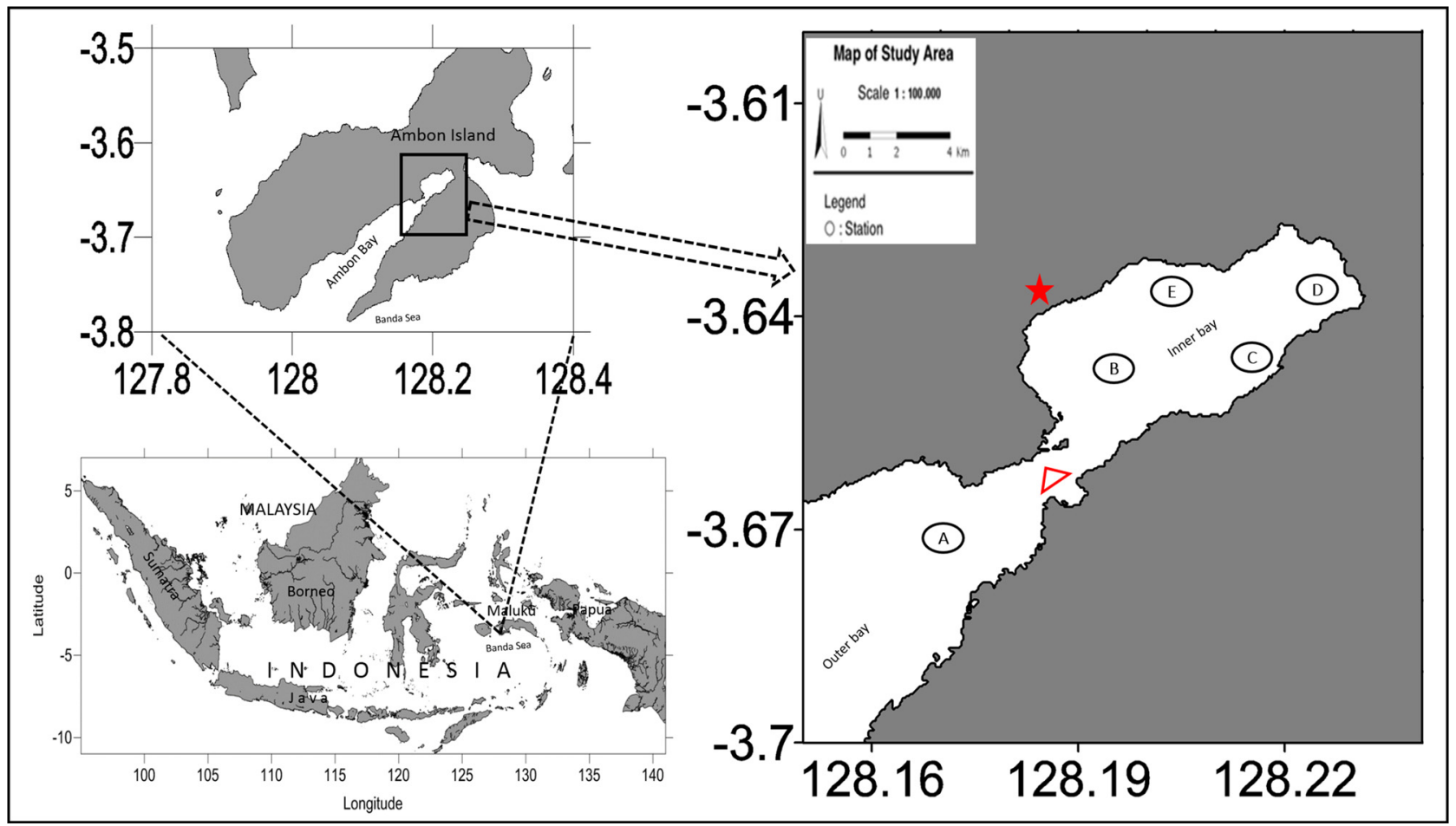

Fig. 1. Map of Ambon Bay with the location of the five sampling stations (A-E). The red star is LIPI, the Centre of Deep Sea Research in Indonesia. The red triangle is the sill. (For interpretation of the references to colour in this figure legend, the reader is referred to the web version of this article).

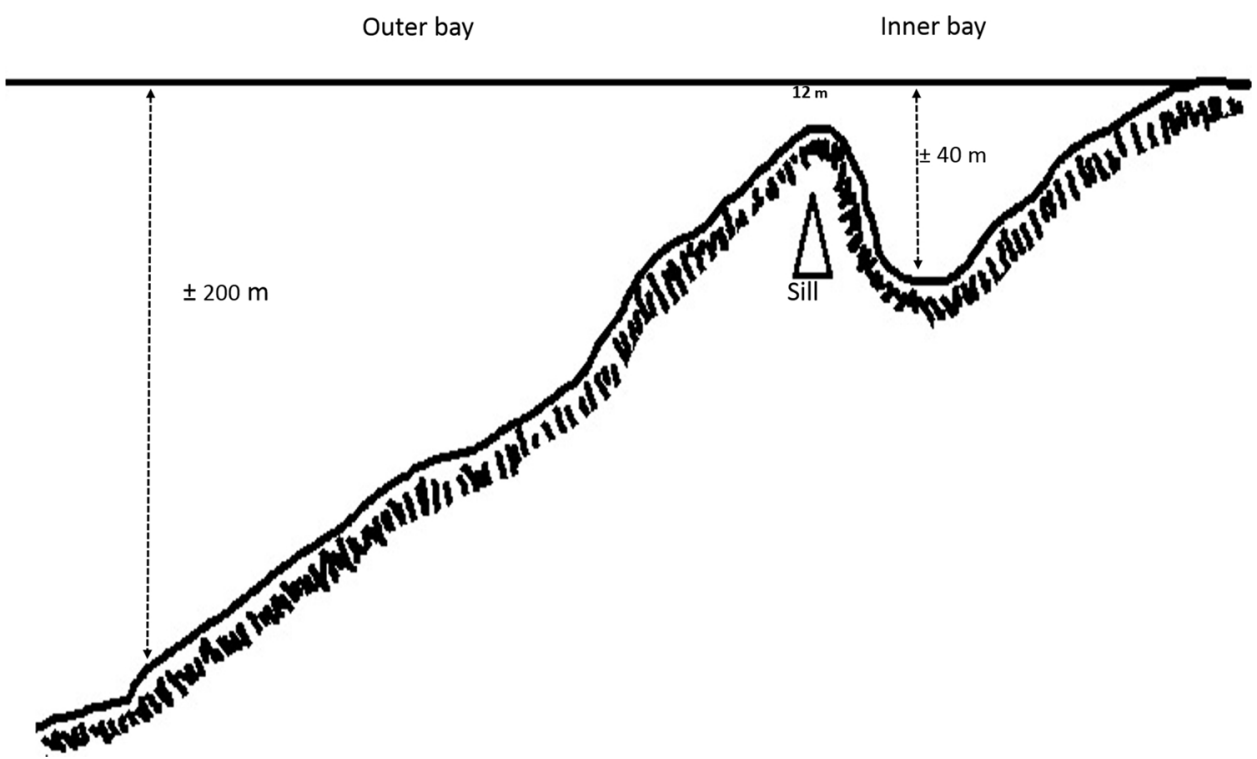

Fig. 2. Ambon Bay cross-section.

box. The final volume of concentrated plankton samples obtained from two net tows was $400 \mathrm{~mL}$, which was processed in the lab for toxin analysis, microscopic observations and spectrophotometric chlorophylla analysis.

\subsection{Sample processing}

\subsubsection{Nutrients}

The pre-filtered water samples were filtered immediately after sampling through a $0.2 \mu \mathrm{m}$ pore size, $47 \mathrm{~mm} \varnothing$ Fisherbrand nylon membrane filter using a vacuum pump with a maximum pressure of 0.3 bar and stored at $-20^{\circ} \mathrm{C}$ until analysis. Samples were analyzed fortnightly using a Spectrophotometer (UV-vis Shimadzu 1700) to measure Nitrate $\left(\mathrm{NO}_{3}\right)$, Phosphate $\left(\mathrm{PO}_{4}\right)$ and Silicate $\left(\mathrm{SiO}_{2}\right)$ following Strickland and Parsons (1972), and Ammonium $\left(\mathrm{NH}_{4}\right)$ following APHA (1998).

\subsubsection{Chlorophyll-a ( $\geq 20 \mu \mathrm{m}$ )}

A five-channel filtration set up was used to process the samples from the five stations immediately after arrival in the lab. Sixty $\mathrm{mL}$ of net sample was filtered through $25 \mathrm{~mm} \emptyset \mathrm{GF} / \mathrm{F}$ Whatman filters using a 0.2 bar vacuum pump. Filters were transferred to darkened glass tubes filled with $10 \mathrm{~mL}$ of $90 \%$ acetone. After mixing, the samples were kept at $4{ }^{\circ} \mathrm{C}$ in a refrigerator. After a few hours, the filters were ground to optimize extraction efficiency using a mini glass spatula and subsequently refrigerated overnight. Samples were centrifuged for $8 \mathrm{~min}$ at 


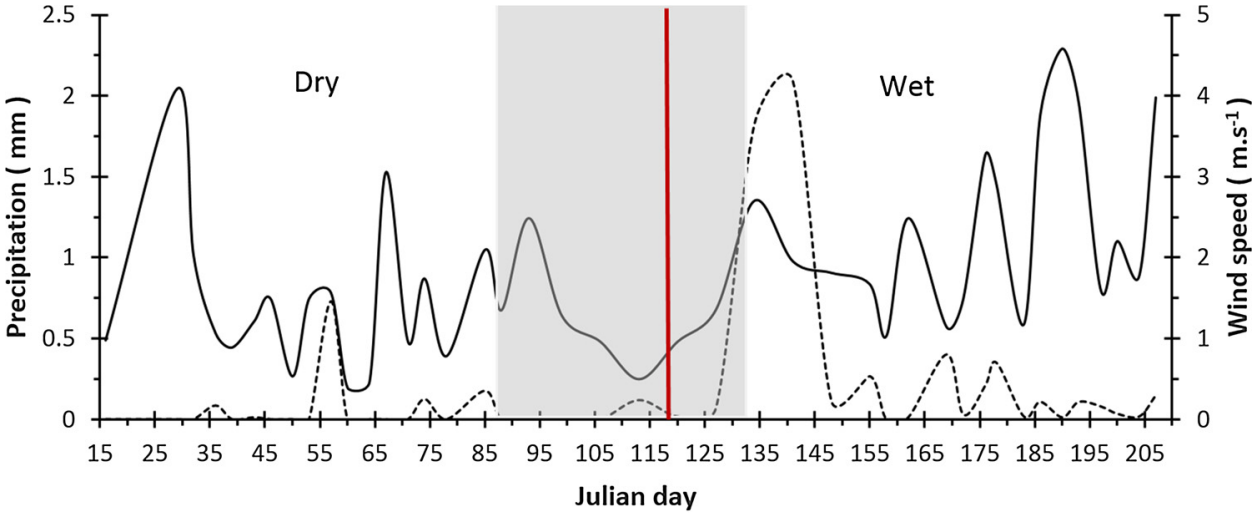

Fig. 3. Weather conditions recorded as average values for $3 \mathrm{~h}$ prior to sampling. The grey area refers to the transition period between dry and wet season. The vertical red line separates the two distinct seasons, as determined by statistical PCA analysis of environmental conditions in 2018. (For interpretation of the references to colour in this figure legend, the reader is referred to the web version of this article). 8,400xg, and measured in a spectrophotometer (UV-vis Shimadzu $1700)$ at wavelengths of 750, 665, 645 and $630 \mathrm{~nm}$. Chlorophyll-a (Chla) was calculated using the equations as described by Strickland and Parsons (1972).

\subsubsection{Pseudo-nitzschia spp. abundance}

Forty $\mathrm{mL}$ of net sample were fixed with acidic lugol iodine solution, and a drop of formalin ( $4 \%$ final concentration) was added to inactivate bacteria. The fixed samples were stored in a $4{ }^{\circ} \mathrm{C}$ refrigerator prior to analysis. Samples were settled in an Uthermöhl $10 \mathrm{~mL}$ sedimentation chamber and inspected at 200x magnification using an Olympus LH50A inverted microscope. To achieve quantitative cell abundances, a minimum of 400 Pseudo-nitzschia spp. cells was counted. The whole chamber was counted when cell densities were low and at higher cell densities a number of randomly chosen fields was inspected until 400 cells were counted. The total abundance of Pseudo-nitzschia spp. was calculated in cells per net tow $\left(\mathrm{NT}^{-1}\right)$. Qualitative microscopic information for the dominant Pseudo-nitzschia species was obtained by an Olympus IMT-2 inverted microscope at 1000x SPlan APO. The cell size was calibrated and treated using Adobe Light Room and Microscope Image Capture and Measurement (MICAM) software, version 2.4.

\subsubsection{Toxin analysis}

Pellets were obtained from $300 \mathrm{~mL}$ of the net samples, concentrated by centrifugation steps at $12,100 \mathrm{x} g$ for $20 \mathrm{~min}$ and transferred to $2 \mathrm{~mL}$ Eppendorf tubes. Pellets were stored at $-30{ }^{\circ} \mathrm{C}$ until further analysis. Particulate domoic acid (pDA) was analysed by liquid chromatography - tandem mass spectrometry (LC-MS/MS). Briefly, cell pellets were transferred to tubes containing ca. $0.9 \mathrm{~g}$ lysing matrix D, and $500 \mu \mathrm{L}$ methanol were added. Extraction was performed at maximum speed $(6.5 \mathrm{~m} / \mathrm{s})$ for $45 \mathrm{~s}$ using a Bio101 FastPrep instrument (Thermo Savant, Illkirch, France). Homogenized samples were centrifuged for $15 \mathrm{~min}$ at $16,100 \mathrm{xg}$ at $4{ }^{\circ} \mathrm{C}$. Supernatants were transferred to spin filters with a pore size of $0.45 \mu \mathrm{m}$ (Milipore Ultrafree, Eschborn, Germany) and centrifuged for $30 \mathrm{~s}$ at $5700 \mathrm{x}$ g. The filtrate was subsequently transferred to HPLC vials for the pDA analysis, according to Krock et al. (2008). The detection limit of pDA in this study was $0.60 \mathrm{ng} \mathrm{NT}^{-1}$.

\subsection{Statistical analysis}

Three hour averages were calculated for wind speed and the rainfall just prior to the sampling trip and used as environmental variables for the statistical analysis. The light extinction coefficient (kd) was calculated by linear regression of log transformed data. Mixed layer depth (MLD) and stratification index were determined using the threshold method as described by González-Pola et al. (2007) and Somavilla et al. (2017). Tidal elevation data were obtained from the Hydrography and Oceanography Centre, Indonesian Navy.
PCA multivariate analysis score plot was employed to distinguish variation among stations and between seasons. The analysis involved all parameters including weather (precipitation and wind speed), physicochemical parameters (the average temperature and salinity $(0-20 \mathrm{~m})$, light attenuation coefficient (kd), MLD, stratification, tidal elevation and nutrients at both depths (2 and $20 \mathrm{~m})$ ) and biological parameters (Chl-a from both net and CTD, pDA and Pseudo-nitzschia spp.). The correlation analysis between Pseudo-nitzschia spp. cell abundance, pDA and environmental factors was performed using a nonparametric Spearman's rank, as the data were not normally distributed. Statistical analysis was done using $\mathrm{R}$ and the Minitab18 package.

\section{Results}

\subsection{Weather variability}

Low average rainfall was found during the dry season, with only six rainy days, ranging between 0.01 and $0.7 \mathrm{~mm}$ of total daily precipitation. Precipitation occurred more frequently during the wet season, starting with two high rainfall days $(1.8$ and $2.0 \mathrm{~mm}$ of total daily precipitation), respectively (Fig. 3). High wind speeds were recorded at the beginning of the year, after which a slightly decreasing trend was observed towards the transition period (Fig. 3). An upward trend in wind speed occurred during the wet season, ranging between $1.0 \mathrm{~m} . \mathrm{s}^{-1}$ on day 158 and $4.6 \mathrm{~m} . \mathrm{s}^{-1}$ on day 190 .

\subsection{Physicochemical characteristics}

Average $(0-20 \mathrm{~m})$ water temperatures showed a downward trend during the sampling period, ranging between $30.2{ }^{\circ} \mathrm{C}$ (day 78 at Station D) and $26.0^{\circ} \mathrm{C}$ (day 141 at Station A). During the dry season, the average temperature increased slightly from $29.2^{\circ} \mathrm{C}$ to $29.9{ }^{\circ} \mathrm{C}$ and started to decrease during the transition period (Fig. 4A). A steady temperature decrease was found during the wet season reaching lowest values at the end of the sampling period. Throughout the campaign, lowest temperatures were found at Station A (Fig. 4A). During the dry and transition seasons, Station D was warmer than the other stations, but was cooler during the subsequent wet season. Similar conditions were observed for the surface water temperature, being slightly warmer than the average at $20 \mathrm{~m}$. Surface temperatures ranged between $31.1^{\circ} \mathrm{C}$ (day 106 at Station D) and $26.4^{\circ} \mathrm{C}$ (day 200 at Station A).

Average salinity $0-20 \mathrm{~m}$ overall showed a slightly upward trend, ranging between 32.5 (day 141 at Station E) and 33.8 (day 197 at Station A). Meanwhile, surface salinity was much lower than the average over $0-20 \mathrm{~m}$, ranging between 27.4 (day 16 at Station D) and 33.6 (day 200 at Station A). Salinity was relatively stable during the dry season, even though there was a slightly downward trend before the transition period (Fig. 4B). During the dry season, the average salinity 

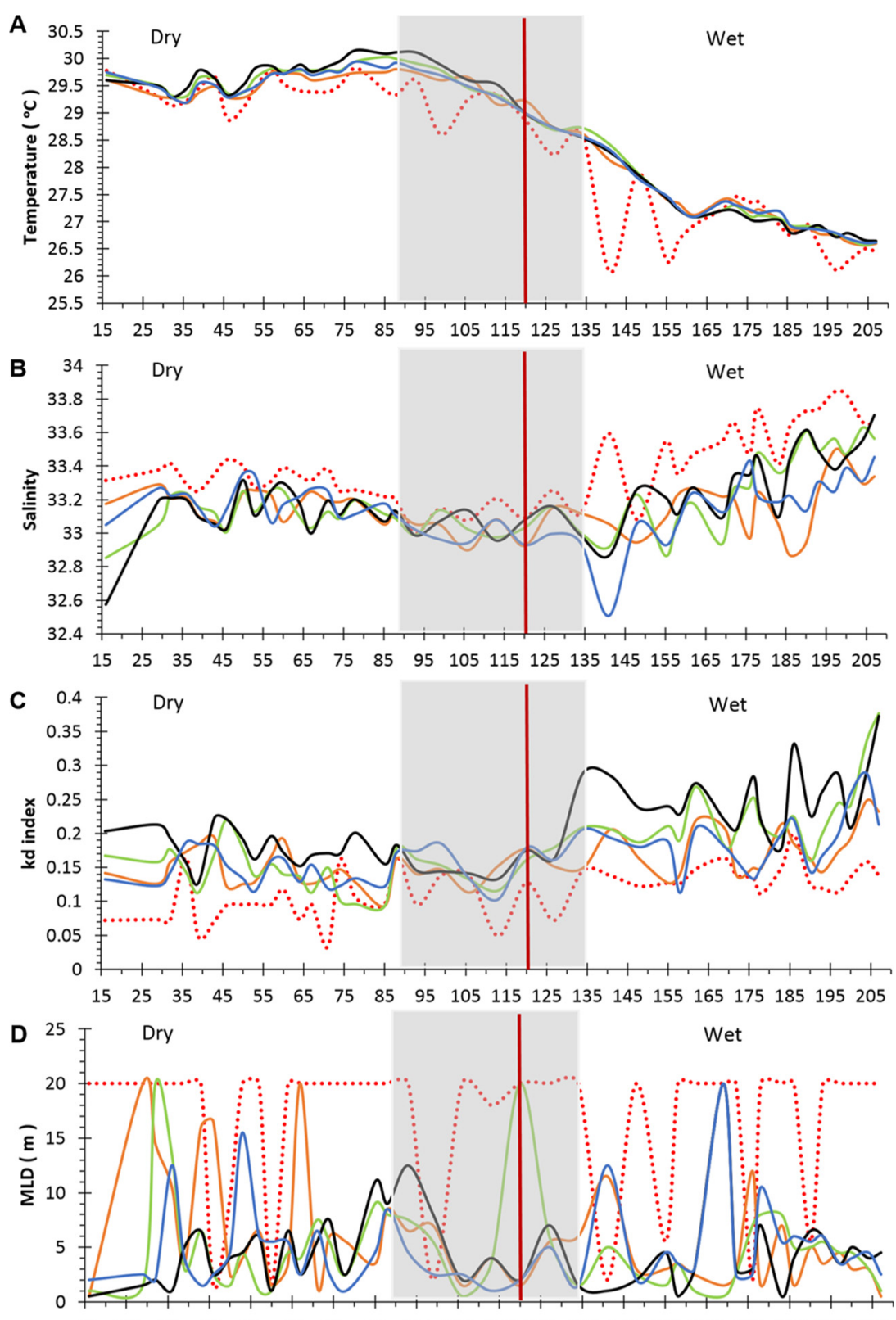

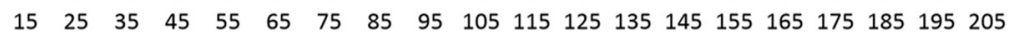

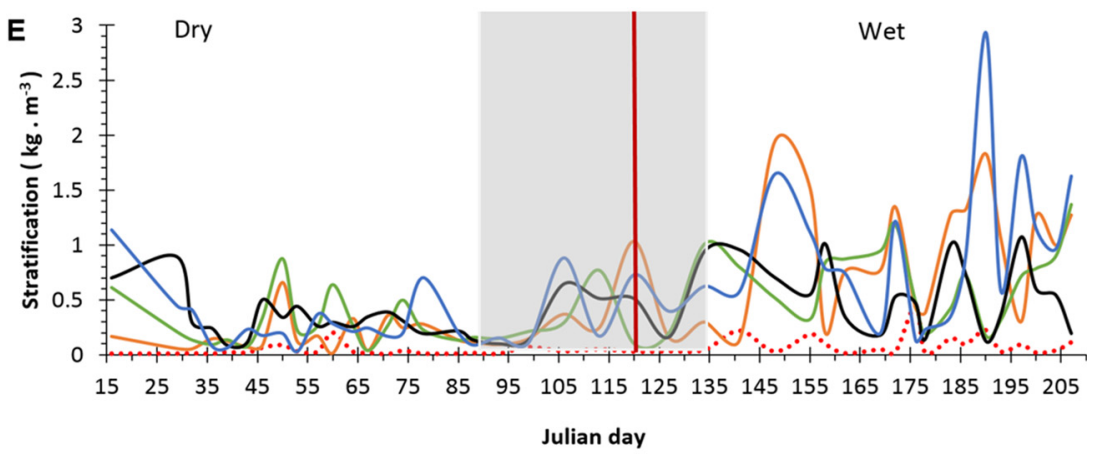

$A-B-C \longrightarrow A$

Fig. 4. Temporal variability of physical properties for the five sampling stations. A: Average water temperature $0-20 \mathrm{~m}$; B: Average salinity $0-20 \mathrm{~m}$; C: Irradiance attenuation kd 0-20 m; D: Mixed Layer Depth (MLD) (m); E: Stratification Index. The grey area refers to the transition period between dry and wet season. The vertical red line separates the two distinct seasons, as determined by statistical PCA analysis of environmental conditions in 2018. (For interpretation of the references to colour in this figure legend, the reader is referred to the web version of this article). 
$0-20 \mathrm{~m}$ ranged between 33.0 and 33.3 , and in the transition period between 33.0 and 33.1. A gradual upward trend occurred during the wet season (Fig. 4B), with the average $0-20 \mathrm{~m}$ ranging between 33.0 and 33.5. Highest salinities were recorded at Station A throughout the campaign. Lowest salinities were found for station D during the dry season, whereas station $\mathrm{B}$ and $\mathrm{E}$ showed lower salinities during the wet season (Fig. 4B). These lower salinities were also observed at the surface.

During the dry season and the transition period irradiance attenuation was stable, ranging between 0.03 (day 71, Station A) and 0.29 (day 134, Station D). An upward trend in kd was observed for all stations during the wet season (Fig. 4C), reaching highest levels towards the end of the campaign (day 207; Station $C=0.37$ and Station $\mathrm{D}=0.38$ ). Lowest $\mathrm{kd}$ values were found for Station A throughout the season, while Station D had the highest kd for both dry and wet seasons.

Mixed layer depth (MLD) was highly variable in space and time. However, a slightly downward trend was found from the dry to the wet season (Fig. 4D). MLD was roughly above $10 \mathrm{~m}$ depth during the wet season for the inner bay stations, interrupted by deep mixing events. Deepest MLDs were found at Station A in the outer bay. Stratification index showed an overall increasing trend from the dry to the wet season (Fig. 4E). During the dry season and the transition period, the stratification index was found below $1 \mathrm{~kg} . \mathrm{m}^{3}$, increasing to $2.9 \mathrm{~kg} \cdot \mathrm{m}^{3}$ at day 190 (Station E) in the wet season. The water column in the inner bay was much more stratified than in the outer bay (Station A: S $0.5 \mathrm{~kg} \cdot \mathrm{m}^{3}$ ), which showed the lowest stratification index throughout the sampling period. Highest indices were found at stations B and E during the wet season.

Phosphate concentration ranged between not detected and $3 \mu \mathrm{M}$ throughout the sampling period. Surface $(2 \mathrm{~m})$ phosphate showed a high variability over time and space, with pronounced peaks in both seasons, yet a gradual decreasing trend was observed for all stations (Fig. 5A). Phosphate concentrations were higher at the inner bay stations compared with station A in the outer bay (Fig. 5A) except for days 16 and 162 . Phosphate concentrations at $20 \mathrm{~m}$, showed similar variability and overall trends as surface levels (Fig. 5B). However, concentrations were generally higher at $20 \mathrm{~m}$. Stations C, D and E showed the highest phosphate levels at $20 \mathrm{~m}$, and station A the lowest.

Generally, surface silicate concentrations were higher (mostly $\geq 10$ $\mu \mathrm{M}$ ) than those at $20 \mathrm{~m}$ (mostly $\leq 10 \mu \mathrm{M}$ ) (Fig. $5 \mathrm{C}$ and D). Both depths showed an upward trend over time. At the end of the wet season, silicate concentrations increased considerably at both depths. Station D showed the highest surface concentrations during the dry season while stations B and $\mathrm{E}$ had highest levels during the wet season. Highest silicate peaks occurred at Stations $\mathrm{C}$ and $\mathrm{D}(52.1 \mu \mathrm{M}$ and $54.2 \mu \mathrm{M}$, respectively) at the end of the season (Fig. 5C). In contrast, station D showed highest silicate levels at $20 \mathrm{~m}$ throughout the sampling period (Fig. 5D).

Although highly variable, nitrate concentrations showed an increasing overall trend during the sampling period, ranging between 0.01 and $3.0 \mu \mathrm{M}$ (Fig. $5 \mathrm{E}$ and F). A clear upward trend occurred at the surface, even though there was a drop by the end of the dry season between days 65 and 90 . Nitrate concentrations started to increase in the transition period, reaching a maximum level of $2.5 \mu \mathrm{M}$ (Station D) in the wet season (Fig. 5E). An opposite trend was found for the concentrations at $20 \mathrm{~m}$ during the dry season, which exhibited a strong decrease during the course of the dry season (Fig. 5F). The highest nitrate level at $20 \mathrm{~m}$ was $3.0 \mu \mathrm{M}$, as found during the beginning of the campaign. Concentrations reached lowest levels by the end of the dry season (day 65-90), similar to the observed surface trends. Station D showed the highest nitrate concentrations both at the surface and the $20 \mathrm{~m}$ samples. Surface nitrate concentration at Station A was similar to the other stations. In contrast, at $20 \mathrm{~m}$, concentrations were lower than at the other stations.

Surface and $20 \mathrm{~m}$ ammonium concentrations increased during the dry season, followed by a decrease during the transition period and subsequent wet season (Fig. $5 \mathrm{G}$ and $\mathrm{H}$ ). Yet, during the wet season, peak ammonia levels were recorded at both depths, $(14.8 \mu \mathrm{M}$, day 200 at Station C). During the wet season, stations A and C showed the highest ammonium concentrations, respectively at the surface $(14.3 \mu \mathrm{M}$ and $13.0 \mu \mathrm{M})$ and at $20 \mathrm{~m}(15.1 \mu \mathrm{M}$ and $14.7 \mu \mathrm{M})$.

\subsection{Chl-a, pDA and Pseudo-nitzschia spp. abundance}

Chlorophyll-a (Chl-a) data was obtained from the net hauls (reflecting the $\geq 20 \mu \mathrm{m}$ phytoplankton fraction) and the CTD measurements, showing a strong positive correlation $(r=0.68$ and $r=0.78$ $(\mathrm{p}=0.00)$, dry and wet season respectively). On average, net Chl-a level was \pm 12 times lower than the CTD Chl-a measurement (results not shown). During the campaign, Chl-a $\geq 20 \mu \mathrm{m}$ showed an upward trend reaching peak levels at the end of the wet season. Chl-a $\geq 20 \mu \mathrm{m}$ levels ranged between 0.01 (day 46, Station A) and $1.8 \mathrm{mg} \mathrm{m}^{3}$ (day 207, Station C), (Fig. 6A). Levels were similar for all stations during the dry season. During the wet season the inner bay stations, in particular B, C and D showed the highest Chl-a $\geq 20 \mu \mathrm{m}$ levels while values remained low at Station A in the outer bay.

Particulate domoic acid (pDA) was detected in all samples, yet, only $51.4 \%$ was found above the detection limit $\left(0.60 \mathrm{ng} \mathrm{NT}^{-1}\right)$. Values of pDA were highly variable over time, showing peaks both in the dry and wet season, mainly at the inner bay stations. Yet, pDA levels showed an upward trend from the dry to the wet season, during which peaks were higher and more frequent, with peak levels up to $3,716 \mathrm{ng} \mathrm{NT}^{-1}$ (day 162, Station D) (Fig. 6B). In the dry season, two pDA peaks were found, on day $53\left(1,218 \mathrm{ng} \mathrm{NT}^{-1}\right)$ and day $85\left(321 \mathrm{ng} \mathrm{NT}^{-1}\right)$ both at station E; in the transition period one small peak was found on day 127 at station D (297 ng NT ${ }^{-1}$ ). During the wet season peaks were found at station D on day $148\left(1,819 \mathrm{ng} \mathrm{NT}^{-1}\right)$ and day $162\left(3,716 \mathrm{ng} \mathrm{NT}^{-1}\right)$, and at station C on day $200\left(465 \mathrm{ng} \mathrm{NT}^{-1}\right)$ and at station $\mathrm{E}$ on day $204\left(463 \mathrm{ng} \mathrm{NT}^{-1}\right)$.

During the campaign, Pseudo-nitzschia spp. cells were observed in 207 out of 210 samples (98.6\%), and the abundance variability showed a similar pattern as compared with pDA levels. The cell abundance observed during the campaign remained relatively low and no Pseudonitzschia blooms occurred. Maximal cell densities were observed during both seasons and showed an overall increasing trend (Fig. 6C). Cell abundances ranged between no cells (day 46, Station C) and $4,456 \times 10^{4}$ cells $\mathrm{NT}^{-1}$ (day 162 , Station $\mathrm{D}$ ). In the dry season, the Pseudo-nitzschia spp. peaked between day 50 and 60, ranging from $40 \times 10^{4}$ to $2,651 \times 10^{4}$ cells $\mathrm{NT}^{-1}$. A small peak in Pseudo-nitzschia spp. cell abundance was found at Station D on day $148\left(374 \times 10^{4}\right.$ cells $\left.\mathrm{NT}^{-1}\right)$, which was followed by a peak density in the wet season between day 158 and $169\left(4,456 \times 10^{4}\right.$ cells NT $\left.{ }^{-1}\right)$. During the dry season, peaks in cell abundance were found at Station E and at Station D during the wet season. Qualitative microscopic inspection revealed the presence of two potentially toxic Pseudo-nitzschia species, of which $P$. pungens was by far the most abundant. The other species was determined as $P$. cf delicatissima, which occurred in relatively low numbers compared with $P$. pungens (data not shown). Species identification was based on average cell size (valve length and width). The cell length of $P$. pungens in this study ranged between 101 and $123 \mu \mathrm{m}$, its width between 3.0 and $4.5 \mu \mathrm{m}$, whereas the number of valve striae per $10 \mu \mathrm{m}$ ranged between 10 and 14 (Fig. 7).

Besides Pseudo-nitzschia spp., the net haul phytoplankton communities were dominated by other diatoms including Chaetoceros spp., Thalassionema nitzschioides and Rhizosolenia spp. In addition, dinoflagellate species were observed throughout, including Gymnodinium catenatum and Dinophysis miles, whereas zooplankton (Copepoda and Meroplankton groups), and fecal pellets were found in high abundance in the net samples. 

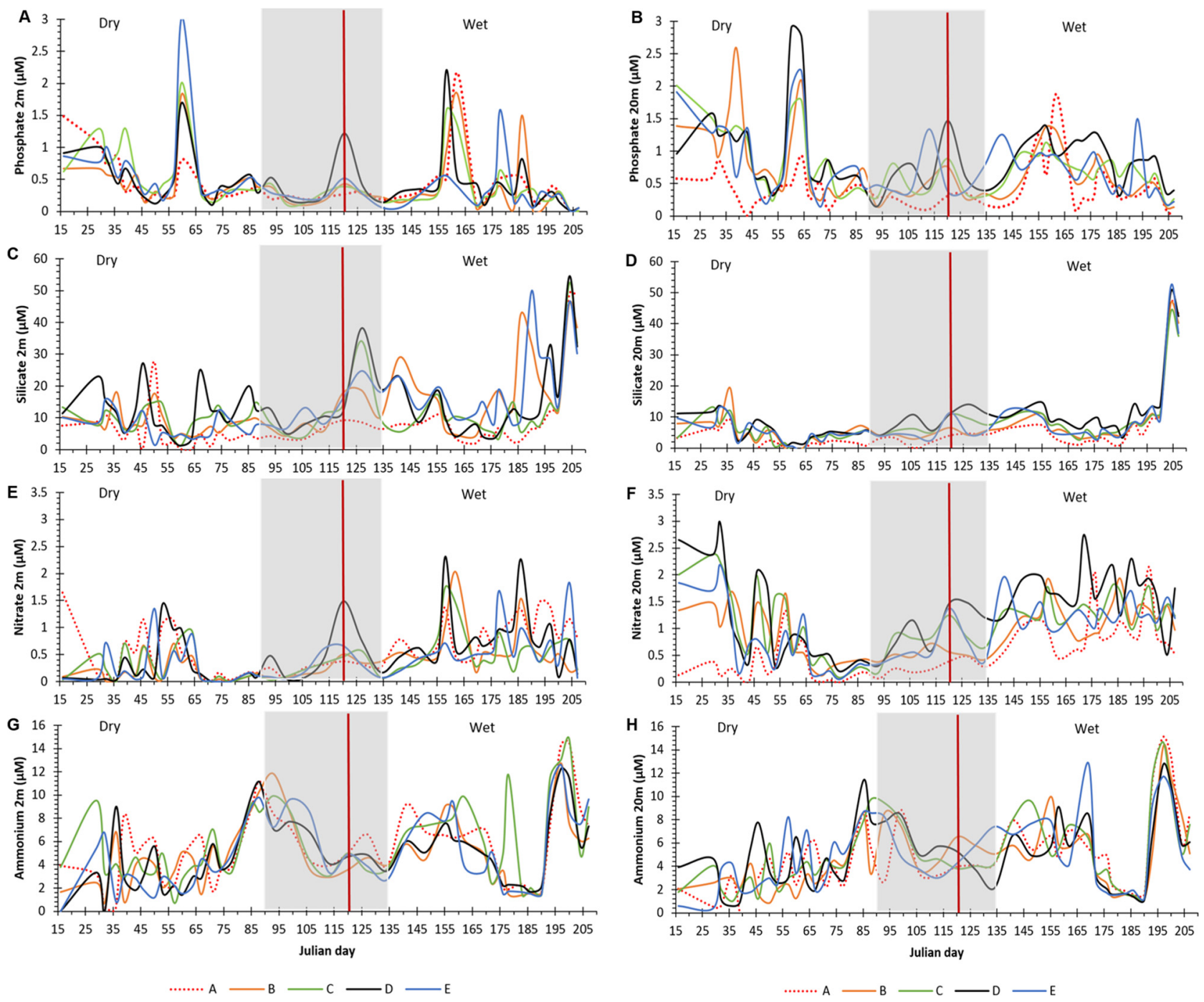

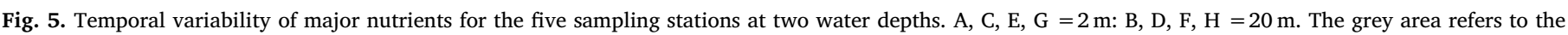

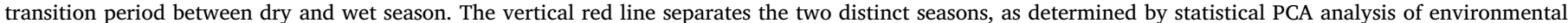
conditions in 2018. (For interpretation of the references to colour in this figure legend, the reader is referred to the web version of this article).

\subsection{Relationship between Pseudo-nitzschia spp., pDA and environmental factors}

Station A was set up as a reference station, located in the outer bay, which was characterized by a higher water depth and oceanic influence. The space resolved PCA score plot $(\mathrm{n}=210)$, when based on all data (stations, weather, physicochemical and biological parameters), indeed showed a clear separation of station A samples from samples of the other stations (Fig. 8A), with only one inner bay data point (station B, day 67) grouping with station A. Apart from station A, no clear space resolved clustering was observed, e.g. for the stations in the inner bay $(\mathrm{n}=168)$. The time resolved PCA score plot (Fig. 8B) showed highly similar characteristics for the dry and the transition period but a clear separation from the wet season $(n=210)$. Four data points of the transition period, belonging to the day where the wet season had just started, revealed the same traits with the wet season. As a result, those points were grouped in the wet season.

Spearman rho regression and analyses was done to investigate possible environmental impacts on Pseudo-nitzschia spp. abundances and pDA levels. Given its strong deviation from the other stations, the outer bay station A was not included further. Moreover, based on the strong seasonal clustering, analyses were done for the dry and wet season separately, whereas data points from the transition period were included in the dry season following the first PCA analysis (Fig. 8B). In this way, the clearest visible regulation of environmental factors on biological properties could be obtained. Spearman rho analysis in the dry season revealed strong positive correlations among Pseudo-nitzschia spp., pDA, MLD and Temperature (Table 1). Phosphate, nitrate and silicate at $20 \mathrm{~m}$ as well as stratification on the other hand negatively correlated with Pseudo-nitzschia spp. and pDA (Table 1). In the wet season, Pseudo-nitzschia spp. and pDA positively correlated with ammonium and negatively correlated with MLD (Table 1).

Spearman rho analysis revealed a strong positive correlation between Pseudo-nitzschia spp. and pDA during both seasons. The correlation in the wet season was stronger than in the dry season, $r=0.87$ $(\mathrm{p}=0.00)$ and $\mathrm{r}=0.66(\mathrm{p}=0.00)$, respectively (Table 1$)$. Pseudonitzschia spp. and pDA showed a strong correlation when based on linear regression in the dry and wet season $\left(R^{2}=0.72\right.$ and 0.63 , respectively, Fig. 9).

\section{Discussion}

This study provides the first evidence of domoic acid (DA) associated with Pseudo-nitzschia spp. in Indonesian waters. Although overall low, pDA and Pseudo-nitzschia spp. were found to be persistent throughout the dry and the wet season in the semi-enclosed Ambon 

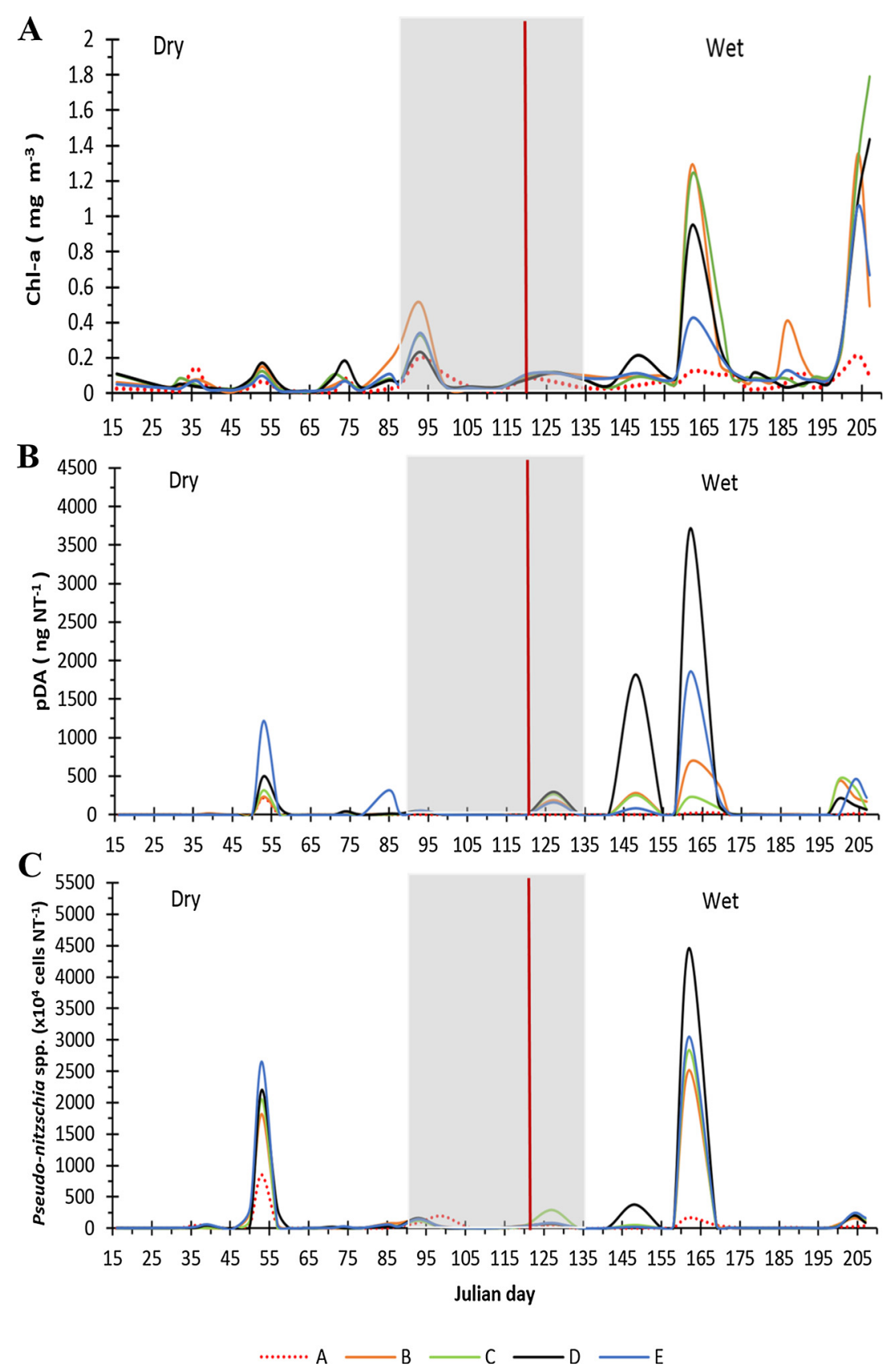

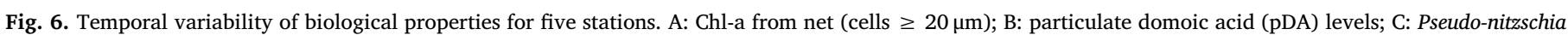

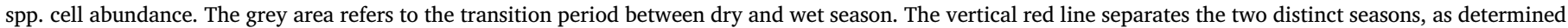

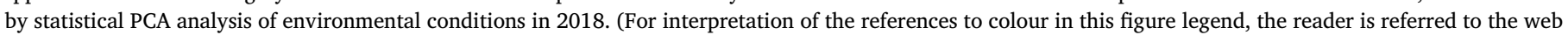
version of this article).

Bay. This implies that the area might potentially be subject to amnesic shellfish poisoning (ASP).

In our study, Pseudo-nitzschia spp. abundances and pDA concentrations were derived from net samples with $20 \mu \mathrm{m}$ mesh size. Although most Pseudo-nitzschia cells occurred in chains, given the average cell width of $3.3 \mu \mathrm{m}$, we cannot exclude that an unknown fraction of cells passed the net. Hence, total Pseudo-nitzschia cells as well as pDA levels might be underestimated in our study. Furthermore, the towing speed of the net ranged between $0.33 \mathrm{~m} / \mathrm{s}$ and $0.29 \mathrm{~m} / \mathrm{s}$, which potentially might have created a $12 \%$ variability in total sampled volume per net tow. Clearly, the choice for using nets is not ideal, yet, when investigating particulate toxin dynamics under non-bloom conditions (like aimed for here), water sample processing (by a.o. Niskins) would not reveal quantitative results sufficiently above the toxins detection limits.

Both cell determination and quantification of Pseudo-nitzschia were performed at the genus level, leading to the total Pseudo-nitzschia spp. abundance. In other words, for practical reasons the most abundant $P$. pungens as well as $P$. cf delicatissima cells were pooled. This implies that if environmental conditions would act in a different way on these two species, this could not be revealed in our study.

The tropical climate of Ambon Island is characterized by seasonal monsoons. During the dry season, high water temperatures are associated with the northwest monsoon, while lower temperatures and high precipitation during the wet season associates with the southeast monsoon. These typical monsoonal characteristics massively influence water physicochemical properties, including Ambon Bay, related with upwelling (southeast monsoon) and sinking (northwest monsoon) 


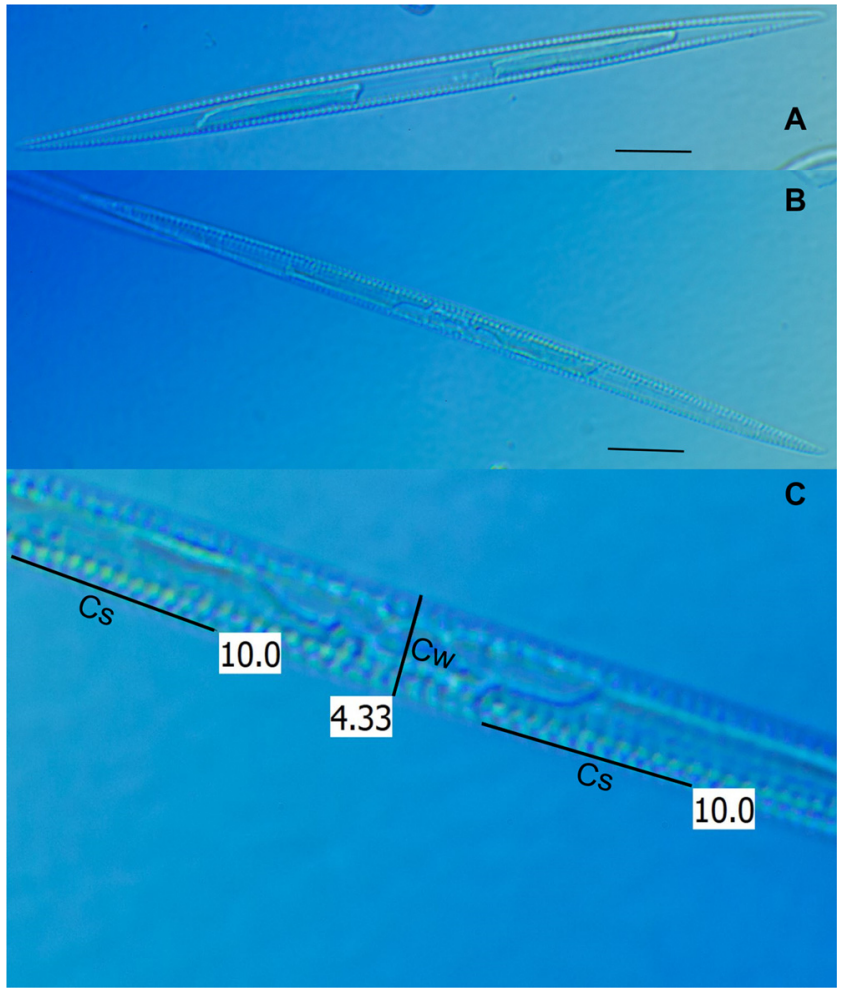

Fig. 7. Light microscope photographs of Pseudo-nitzschia pungens cells, found in Ambon Bay in 2018. (A) A single cell (scale bar $=10 \mu \mathrm{m}$ ). (B) Valve view (scale bar $=10 \mu \mathrm{m})$. (Cw) Cell width $(\mu \mathrm{m})$. (Cs) 13-14 striae per $10 \mu \mathrm{m}$.

processes in the Banda Sea (Wyrtki, 1961; Boëly et al., 1990; Zijlstra et al., 1990). In our study, the decrease in water temperature and increase in salinity (Fig. 4 A and B) as observed during the wet season indicated the onset of upwelling in the Banda Sea, affecting all stations in Ambon Bay, but most of all Station A. Similar events had been shown earlier by Saputra and Lekalette (2016), where cold-saline water at $20 \mathrm{~m}$ or lower showed enhanced intrusion of the inner bay during the southeast monsoon as the result of tidal force upwelling in the Banda Sea. In addition, more than $70 \%$ of upwelled water from the outer bay had been found to replace local water masses in the inner bay (Riantika, 2011 (data not published); Corvianawatie et al., 2014).

Other monsoon related factors controlling physical water properties include wind speed and precipitation, which might have opposing effects on mixed layer depth and stratification. Yet, as found in the present study, enhanced wind speeds in the wet season did not lead to deeper mixed layers in the inner bay (Figs. 3 and 4D). Instead, the increase in precipitation on average caused elevated irradiance attenuation due to enhanced runoff as well as water column stratification, although occasional strong winds caused regular stratification breakdown (Figs. 3, 4C and E).

During the southeast monsoon (wet season) nutrient variability showed upward trends at both water depths, likely caused by elevated precipitation and associated runoff. However, our data did not show strong positive correlations between precipitation and nutrient concentrations during the wet season. This might be due to rapid flushing processes in the bay, promoted by the deep water intrusion. The residence time in the inner bay has been calculated to be less than 14 days (Pello et al., 2014). Meanwhile, high nutrient concentrations at the beginning of the year might be due to mixing events caused by the observed high wind speeds during January and February (Fig. 3). Similar results were found between 2012 and 2015, where high nutrient concentrations were detected at the start of the northwest monsoon, declining during the transition period, and subsequently increasing during the southeast monsoon (LIPI monitoring program, not published). Ikhsani et al. (2016) reported that high nutrient levels during the southeast monsoon (wet season) in the inner Ambon Bay could be regulated by runoffs as well as cold-nutrient rich upwelled water entering from the outer bay, implying that intermonsoonal and -annual variability in precipitation may partly be responsible for the observed nutrient dynamics in our study.

Throughout the dry and wet season, Pseudo-nitzschia spp. was found to be persistent in the bay. Abundance maxima found in this study were relatively low compared to other locations (Klein et al., 2010; Bowers et al., 2018; Liefer et al., 2013; Vilas et al., 2014) including Asia (Teng et al., 2013). Interestingly, Pseudo-nitzschia spp. abundance strongly correlated with pDA levels throughout the campaign (Fig. 9). The average toxin cell quota in this study varied among seasons, which was higher during the wet season (on average $0.4 \mathrm{pg} \mathrm{DA} \mathrm{cell}^{-1}$; ranging between 0.01 and $4.1 \mathrm{pg} \mathrm{DA}$ cell $^{-1}$ ) than during the dry season (on average $0.1 \mathrm{pg}$ DA cell ${ }^{-1}$; ranging between 0 and $0.6 \mathrm{pg}$ DA cell ${ }^{-1}$ ). Previous field studies had shown weak correlations between Pseudonitzschia and DA level (Bates et al., 1998; Klein et al., 2010; reviewed by Lelong et al., 2012). Delegrange et al. (2018) found Pseudo-nitzschia and DA to be correlated in spring $\left(0.02 \mathrm{pg}\right.$ DA cell $\left.{ }^{-1}\right)$ but not during the rest of season in the southern North Sea. In contrast, DA was found to correspond to Pseudo-nitzschia abundance in the Southern California Bight during two years of monitoring (2013 (5.7 \pm 10.6 pg DA cell $\left.^{-1}\right)$; 2014 (0.3 $\left.\pm 0.9 \mathrm{pg} \mathrm{DA} \mathrm{cell}^{-1}\right)$ ) (Smith et al., 2017). Moreover, Pseudonitzschia blooms were found to be associated with high DA levels in the eddy area of Juan de Fuca (Trainer et al., 2002, reviewed by Trainer et al., 2012). Umhau et al. (2018) found a significant correlation between particulate DA and Pseudo-nitzschia abundance in an offshore area of Santa Barbara Basin, California $\left(37 \pm 124\right.$ pg DA cell $\left.^{-1}\right)$. In the Bay of Seine, France, high DA concentrations were correlated with Pseudo-nitzschia australis, $P$. pungens and $P$. fraudulenta, but no correlation was found with a bloom of $P$. delicatissima (Thorel et al., 2017). The observed high variability in DA content may be related to species or strain specific differences, apart from cell specific DA variability related with environmental conditions such as nutrients, temperature or biotic influences (Trainer et al., 2012; Lelong et al., 2012).

The persistent occurrence of pDA and strong correlations with Pseudo-nitzschia spp. abundance as found in the present study imply that this species thrives and survives in Ambon Bay throughout the seasons. Even though detailed taxonomic identification based on electron microscope could not be done, the morphology of the most dominant Pseudo-nitzschia cells showed highly similar traits to P. pungens (Fig. 7). Based on the distribution of Pseudo-nitzschia species around the world, $P$. pungens is ubiquitously distributed in both tropical and temperate waters (Naz et al., 2012; Lim et al., 2014; Kim et al., 2015). Furthermore, P. pungens is regularly observed in Indonesian waters, yet toxin analyses were not reported before (Trainer et al., 2012; Lelong et al., 2012).

Several environmental factors stimulated both Pseudo-nitzschia spp. abundance and pDA levels in the bay, but these factors differed between seasons (Table 1). Spearman Rho Analysis showed no clear single factor that strongly governed Pseudo-nitzschia spp. abundance and pDA. Yet, ammonium was found as the main factor that correlated with Pseudonitzschia spp. abundance and pDA throughout the seasons. High constant ammonium availability, exceeding that of nitrate (Fig. 5E-H), might benefit persistent Pseudo-nitzschia growth and pDA production in the bay. Wastewater is discharged continuously in Ambon Bay supporting nitrification of ammonium as well as direct uptake, providing a substantial nitrogen source for the primary producers (McLaughlin et al., 2017), including Pseudo-nitzschia and its toxin (Cochlan et al., 2008; Auro and Cochlan, 2013; Martin-Jézéquel et al., 2015). By utilizing multiple nitrogen resources such as ammonium, urea and nitrate, Pseudo-nitzschia had demonstrated a persistent growth and enhanced toxin production (Thessen et al., 2009). The presence of fish farms in Ambon Bay, especially near stations C, D and E might contribute further to nitrogen input, however, no clear spatial differences in Pseudo- 


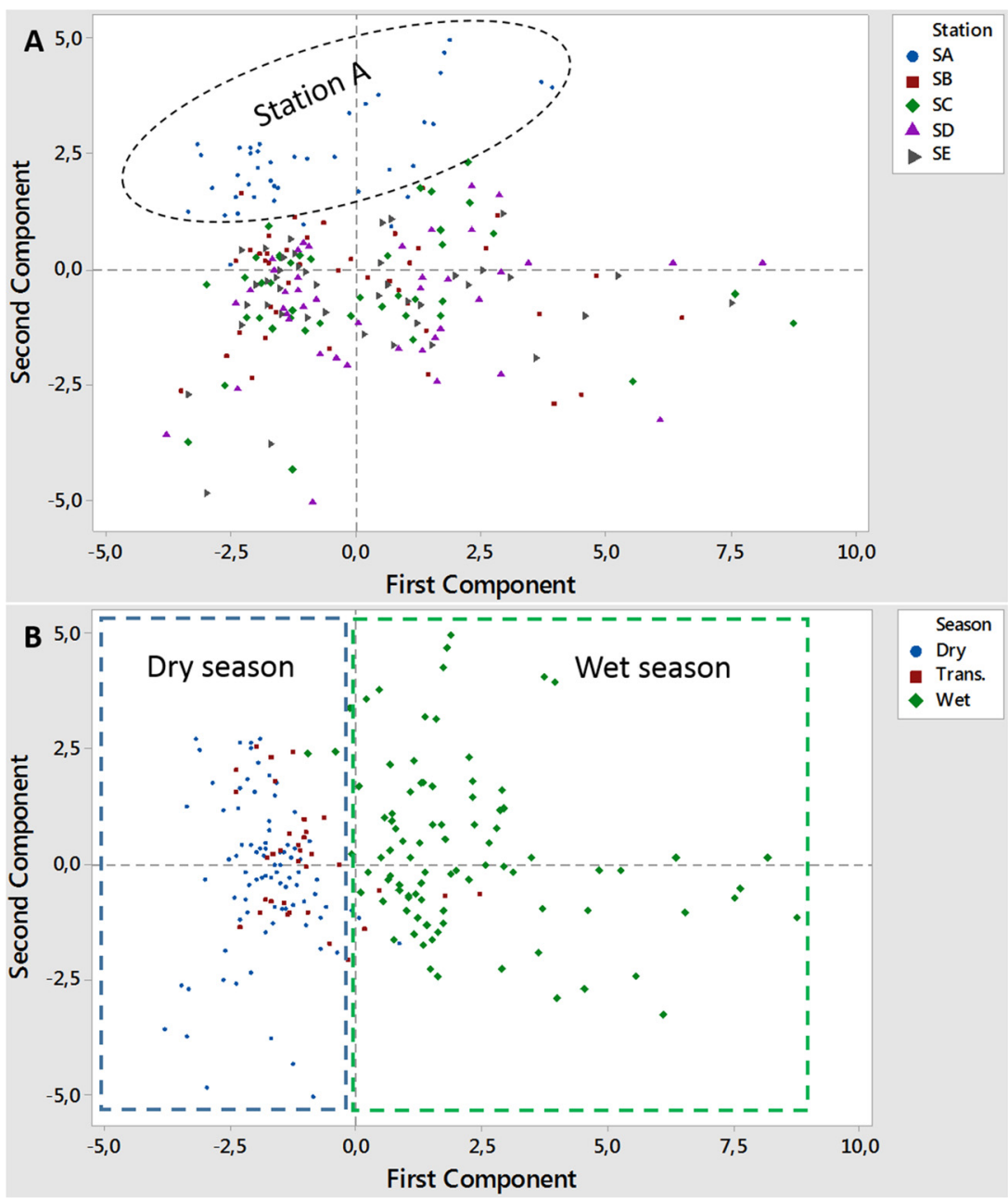

Fig. 8. PCA analysis of weather, environmental and biological data represent station (A) and season (B) groupings based on score plots (n = 210).

Table 1

Spearman rho correlations between Pseudo-nitzschia spp., particulate domoic acid (pDA) and environmental properties (Abbreviations; MLD (Mixed Layer Depth), P0 (Phosphate $2 \mathrm{~m}$ ), No (Nitrate at surface $2 \mathrm{~m}$ ), S0 (Silicate $2 \mathrm{~m}$ ), A0 (Ammonium $2 \mathrm{~m}$ ), P20 (Phosphate $20 \mathrm{~m}$ ), N20 (Nitrate $20 \mathrm{~m}$ ), S20 (Silicate $20 \mathrm{~m}$ ), A20 (Ammonium $20 \mathrm{~m}$ ), Chl-a net (Chlorophyll-a $\geq 20 \mu \mathrm{m}$ from the net)).

\begin{tabular}{|c|c|c|c|c|}
\hline \multirow{2}{*}{$\begin{array}{l}\text { Environmental } \\
\text { factors }\end{array}$} & \multicolumn{2}{|c|}{ Dry season $(\mathrm{n}=96)$} & \multicolumn{2}{|c|}{ Wet season $(n=72)$} \\
\hline & $\begin{array}{l}\text { Pseudo- } \\
\text { nitzschia spp. }\end{array}$ & pDA & $\begin{array}{l}\text { Pseudo- } \\
\text { nitzschia spp. }\end{array}$ & pDA \\
\hline $\begin{array}{l}\text { Pseudo-nitzschia } \\
\text { spp. }\end{array}$ & - & $r=0.66^{* * *}$ & - & $\mathrm{r}=0.87^{* * *}$ \\
\hline MLD & $\mathrm{r}=0.35^{* * *}$ & $\mathrm{r}=0.32^{* * *}$ & $\mathrm{r}=-0.28^{*}$ & $\mathrm{r}=-0.28^{*}$ \\
\hline Stratification & $\mathrm{r}=-0.28^{* *}$ & $r=-0.24^{*}$ & nc & nc \\
\hline Temperature & nc & $\mathrm{r}=0.5^{* * *}$ & nc & nc \\
\hline Salinity & nc & nc & nc & nc \\
\hline Precipitation & $r=-0.26^{*}$ & $\mathrm{r}=-0.24^{*}$ & nc & $\mathrm{nc}$ \\
\hline P0 & nc & $\mathrm{r}=-0.24^{*}$ & nc & nc \\
\hline N0 & nc & nc & $\mathrm{nc}$ & nc \\
\hline so & nc & nc & $\mathrm{nc}$ & nc \\
\hline A0 & $\mathrm{r}=0.23^{*}$ & $\mathrm{r}=0.24 *$ & $\mathrm{r}=0.24 *$ & nc \\
\hline P20 & $\mathrm{r}=-0.4 * * *$ & $\mathrm{r}=-0.5^{* * *}$ & $\mathrm{nc}$ & nc \\
\hline $\mathrm{N} 20$ & $\mathrm{r}=-0.21^{*}$ & $\mathrm{r}=-0.4^{* * *}$ & $\mathrm{nc}$ & nc \\
\hline S20 & nc & $\mathrm{r}=-0.23^{*}$ & nc & nc \\
\hline A20 & nc & $\mathrm{r}=0.3^{* * *}$ & $\mathrm{r}=0.25^{*}$ & $\mathrm{r}=0.26^{*}$ \\
\hline Chl-a net & $\mathrm{r}=0.6^{* * *}$ & $\mathrm{r}=0.57^{* * *}$ & $\mathrm{r}=0.84^{* * *}$ & $\mathrm{r}=0.77^{* * *}$ \\
\hline
\end{tabular}

Remarks: ${ }^{* * *} \mathrm{p}=0.00 ; * * \mathrm{p} \leq 0.01 ; * \mathrm{p} \leq 0.05 ;$ nc (not correlated). nitzschia spp. as well as pDA level were found. The other nutrients (phosphate, nitrate and silicate) inversely correlated with both Pseudonitzschia spp. and pDA in the dry season. Similar negative correlations were observed in the San Pedro Channel and Los Angeles harbor in Southern California (Schnetzer et al., 2007) and in the Western English Channel (UK) (Downes-Tettmar et al., 2013). Meanwhile, in the period of higher nutrient availability during the wet season, both particulate DA levels (Fig. 6B) and DA cell quotas were found to be higher. In both seasons, peaks of pDA were found when phosphate and silicate decreased dramatically, implying that the lack of these nutrients increased toxin production. In accordance with this result, previous studies both in the field and lab experiments had shown that phosphate and silicate limitation triggered high DA production in Pseudo-nitzschia (Fehling et al., 2004; Lelong et al., 2012; Trainer et al., 2012; Tatters et al., 2012; Parson et al., 2013; Terseleer et al., 2013; Lema et al., 2017; Bowers et al., 2018).

In our study, Pseudo-nitzschia spp. and pDA were positively correlated with mixed layer depth in the dry season but negatively correlated in the wet season. In addition, a strong positive correlation between pDA and temperature occurred during the dry season. Strong and warm winds blow in Ambon Island during the northwest monsoon provoking upper water mixing in the inner bay, enriching the water column with nutrient rich bottom water. During the wet season however, nutrient rich freshwater input enhances water column stratification despite elevated wind speeds. Coupled with the runoff discharges, the upwelling onset with high nutrient concentration seemed to fuel Pseudonitzschia spp. growth and more pDA production during the southeast 


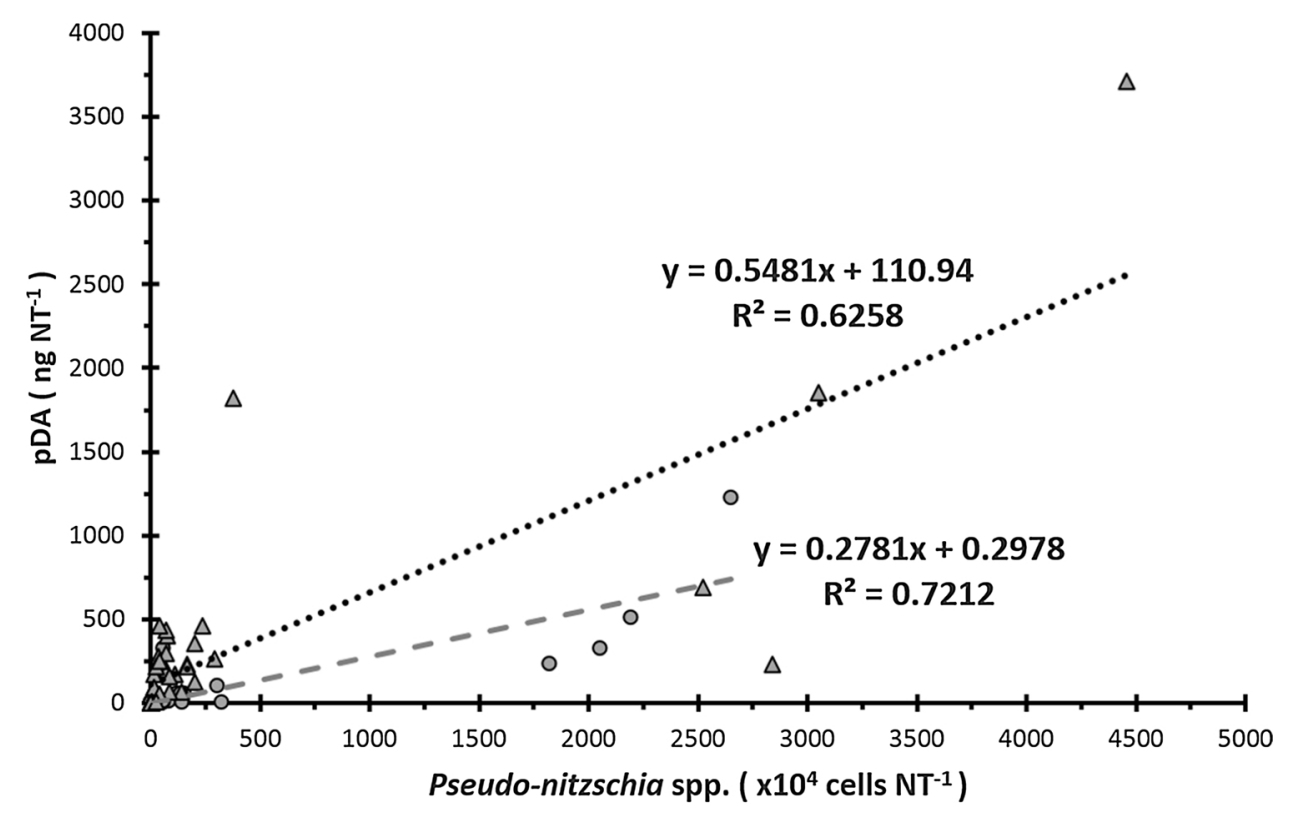

\section{○ Dry $\Delta$ Wet $\quad-$ - Linear (Dry) $\quad \ldots$.... Linear (Wet)}

Fig. 9. Linear regression model of Pseudo-nitzschia spp. cell abundance versus pDA during the dry and wet season.

monsoon, even though cell abundances were moderate and no blooms were found. In Monterey Bay, increases of Pseudo-nitzschia cell density coincided with upwelled nutrient-rich water (Bowers et al., 2018). Meanwhile, high DA levels were associated with relatively low sea surface temperature and high salinity in the Santa Barbara Channel (Anderson et al., 2009). Temperature dependent DA and Pseudo-nitzschia responses vary between regions, seasons and species as has been shown by both field and laboratory studies (Amato et al., 2010; Klein et al., 2010; Ljubešić et al., 2011; Marić et al., 2011; Hansen et al., 2011; Sahraoui et al., 2012; Thorel et al., 2014; Kim et al., 2015; Bresnan et al., 2017). In the subtropical Gulf of Mexico, the average temperature during the Pseudo-nitzschia spp. bloom period was $28 \pm 1.3^{\circ} \mathrm{C}$ (Liefer et al., 2013), which was similar to sea water temperatures in Ambon Bay during both seasons.

\section{Conclusions}

In conclusion, several environmental conditions seem to govern Pseudo-nitzschia spp. and pDA in Ambon Bay, of which ammonium variability seems the most pronounced. Thus, based on the present data, the prediction of future Pseudo-nitzschia spp. outbreaks is problematic, although factors like human population growth affecting waste water discharge, and elevated precipitation as well as land discharges through massive runoffs during the wet season might stimulate Pseudo-nitzschia spp. through enhanced stratification and nutrient (ammonium) input. Furthermore, possible influences of biotic factors including grazers (Leandro et al., 2010; Tammilehto et al., 2012; Selander et al., 2019), allelopathy (Van Meerssche et al., 2018) and bacteria (Lelong et al., 2012; Sison-Mangus et al., 2014) were not determined and therefore need to be addressed in future studies. pDA and Pseudo-nitzschia spp. were observed throughout the year during both the dry and wet season, implying that Ambon Bay might be potentially subject to amnesia shellfish poisoning. Thus, future research needs to reveal if the observed low but persistent DA levels accumulate in local shellfish, thereby causing a potential threat for the environment as well as human health.

\section{Author declaration}

Submission of an article implies that the work described has not been published previously (except in the form of an abstract or as part of a published lecture or academic thesis), that it is not under consideration for publication elsewhere, that its publication is approved by all authors and tacitly or explicitly by the responsible authorities where the work was carried out, and that, if accepted, it will not be published elsewhere in the same form, in English or in any other language, without the written consent of the copyright-holder.

By attaching this Declaration to the submission, the corresponding author certifies that:

- The manuscript represents original and valid work and that neither this manuscript nor one with substantially similar content under the same authorship has been published or is being considered for publication elsewhere.

- Every author has agreed to allow the corresponding author to serve as the primary correspondent with the editorial office, and to review the edited typescript and proof.

- Each author has given final approval of the submitted manuscript and order of authors. Any subsequent change to authorship will be approved by all authors.

- Each author has participated sufficiently in the work to take public responsibility for all the content.

\section{Acknowledgements}

We thank Thomas Max and Annegret Müller for assisting and analyzing domoic acid, Ronald Visser for preparing and setting up equipment in Ambon, Dr. Augy Syahailatua for allowing us to work in the LIPI's plankton laboratory, Ambon, and Christophe Brochard for performing qualitative microscopic analysis. This work was supported and funded by LPDP program (Nomor: PRJ-1007/LPDP.3/2016), the Indonesian Ministry of Finance and partially funded by the HelmholtzGemeinschaft Deutscher Forschungszentren through the research program PACES II of the Alfred Wegener Institut-Helmholtz Zentrum für Polar- und Meeresforschung [CG].

\section{References}

Aditya, V., Koswara, A., Fitriya, N., Rachman, A., Sidabutar, T., Thoha, H., 2013. Public 
awareness on harmful algal bloom (HAB) in Lampung Bay. Mar. Res. Indonesia 38 (2), 71-75.

Almandoz, G.O., Fabro, E., Ferrario, M., Tillmann, U., Cembella, A., Krock, B., 2017. Species occurrence of the potentially toxigenic diatom genus Pseudo-nitzschia and the associated neurotoxin domoic acid in the Argentine Sea. Harmful Algae 63, 45-55.

Amato, A., Lüdeking, A., Kooistra, W.H., 2010. Intracellular domoic acid production in Pseudo-nitzschia multistriata isolated from the Gulf of Naples (Tyrrhenian Sea, Italy). Toxicon 55 (1), 157-161.

Anderson, C.R., Brzezinski, M.A., Washburn, L., Kudela, R., 2006. Circulation and environmental conditions during a toxigenic Pseudo-nitzschia australis bloom in the Santa Barbara Channel, California. Mar. Ecol. Prog. Ser. 327, 119-133.

Anderson, C.R., Siegel, D.A., Kudela, R.M., Brzezinski, M.A., 2009. Empirical models of toxigenic Pseudo-nitzschia blooms: potential use as a remote detection tool in the Santa Barbara Channel. Harmful Algae 8 (3), 478-492.

APHA, 1998. Standard Methods for the Examination of Water and Wastewater, 20th ed. American Public Health Association, American Water Works Association and Water Environmental Federation, Washington DC.

Auro, M.E., Cochlan, W.P., 2013. Nitrogen utilization and toxin production by two diatoms of the Pseudo-nitzschia pseudodelicatissima Complex: P. cuspidata and P. fryxelliana. J. Phycol. 49 (1), 156-169.

Azanza, R.V., Taylor, F.J.R., 2001. Are Pyrodinium blooms in the Southeast Asian region recurring and spreading? A view at the end of the millennium. AMBIO 30, 356-364.

Bates, S.S., Trainer, V.L., 2006. The ecology of harmful diatoms. In: Graneli, E., Turner, J.T. (Eds.), Ecology of Harmful Algae. Springer-Verlag, Berlin p. 440.

Bates, S.S., Bird, C.J., de Freitas, A.S.W., Foxall, R., Gilgan, M., Hanic, L.A., Johnson, G.R., McCullough, A.W., Odense, P., Pocklington, R., Quilliam, M.A., Sim, P.G., Smith, J.C., Subba Rao, D.V., Todd, E.C.D., Walter, J.A., Wright, J.L.C., 1989. Pennate diatom Nitzschia pungens as the primary source of domoic acid, a toxin in shellfish from eastern Prince Edward Island, Canada. Can. J. Fish. Aquat. Sci. 46, 1203-1215. https://doi.org/10.1139/f89-156.

Bates, S.S., Garrison, D.L., Horner, R.A., 1998. Bloom dynamics and physiology of domoic acid-producing Pseudo-nitzschia species. In: Anderson, D.M., Cembella, A.D., Hallegraeff, G.M. (Eds.), Physiological Ecology of Harmful Algal Blooms. SpringerVerlag, Heidelberg p. 267.

Bates, S.S., Hubbard, K.A., Lundholm, N., Montresor, M., Leaw, C.P., 2018. Pseudo-nitzschia, Nitzschia, and domoic acid: new research since 2011. Harmful Algae 79, 3-43.

Bejarano, A.C., VanDola, F.M., Gulland, F.M., Rowles, T.K., Schwacke, L.H., 2008. Production and toxicity of the marine biotoxin domoic acid and its effects on wildlife: a review. Hum. Ecol. Risk Assess. 14 (3), 544-567.

Bowers, H.A., Ryan, J.P., Hayashi, K., Woods, A.L., Marin III, R., Smith, G.J., Hubbard, K.A., Doucette, G.J., Mikulski, C.M., Gellene, A.G., Zhang, Y., Kudela, R.M., Caron, D.A., Birch, J.M., Scholin, C.A., 2018. Diversity and toxicity of Pseudo-nitzschia species in Monterey Bay: perspectives from targeted and adaptive sampling. Harmful Algae 78, 129-141.

Boëly, T., Gastellu-Etchegorry, J.P., Potier, M., Nurhakim, S., 1990. Seasonal and interannual variations of the sea surface temperatures (SST) in the Banda and Arafura Sea area. J. Sea Res. 25 (4), 425-429.

Bresnan, E., Fryer, R.J., Fraser, S., Smith, N., Stobo, L., Brown, N., Turrell, E., 2017. The relationship between Pseudo-nitzschia (Peragallo) and domoic acid in Scottish shellfish. Harmful Algae 63, 193-202.

Cochlan, W.P., Herndon, J., Kudela, R.M., 2008. Inorganic and organic nitrogen uptake by the toxigenic diatom Pseudo-nitzschia australis (Bacillariophyceae). Harmful Algae 8 (1), 111-118.

Corvianawatie, C., Putri, M.R., Cahyarini, S.Y., Tatipatta, W.M., 2014. Variability of sea surface temperature and sea surface salinity in the Ambon Bay and its relation to ENSO/IOD and monsoon. Indonesian J. Geospatial 3 (2), 1-8.

Delegrange, A., Lefebvre, A., Gohin, F., Courcot, L., Vincent, D., 2018. Pseudo-nitzschia sp. diversity and seasonality in the southern North Sea, domoic acid levels and associated phytoplankton communities. Estuar. Coast. Shelf S. 214, 194-206.

Downes-Tettmar, N., Rowland, S., Widdicombe, C., Woodward, M., Llewellyn, C., 2013. Seasonal variation in Pseudo-nitzschia spp. and domoic acid in the Western English Channel. Cont. Shelf Res. 53, 40-49.

Fabro, E., Almandoz, G.O., Ferrario, M., Tillmann, U., Cembella, A., Krock, B., 2016. Distribution of Dinophysis species and their association with lipophilic phycotoxins in plankton from the Argentine Sea. Harmful Algae 59, 31-41.

Fehling, J., Davidson, K., Bolch, C.J., Bates, S.S., 2004. Growth and domoic acid production by Pseudo-nitzschia seriata (bacillariophyceae) under phosphate and silicate limitation. J. Phycol. 40 (4), 674-683.

Fire, S.E., Wang, Z., Berman, M., Langlois, G.W., Morton, S.L., Sekula-Wood, E., BenitezNelson, C.R., 2010. Trophic transfer of the harmful algal toxin domoic acid as a cause of death in a Minke Whale (Balaenoptera acutorostrata) Stranding in Southern California. Aquat. Mamm. 36 (4).

González-Pola, C., Fernández-Díaz, J.M., Lavín, A., 2007. Vertical structure of the upper ocean from profiles fitted to physically consistent functional forms. Deep-Sea Res. Pt. I 54 (11), 1985-2004.

Hansen, L.R., í Soylu, S., Kotaki, Y., Moestrup, Ø., Lundholm, N., 2011. Toxin production and temperature-induced morphological variation of the diatom Pseudo-nitzschia seriata from the Arctic. Harmful Algae 10 (6), 689-696.

Ikhsani, I.Y., Abdul, M.S., Lekalette, J.D., 2016. Distribusi fosfat dan nitrat di Teluk Ambon bagian dalam pada musim barat dan timur. Widyariset 2 (2), 86-95 (in Indonesian, with English abstract).

Kim, J.H., Park, B.S., Kim, J.H., Wang, P., Han, M.S., 2015. Intraspecific diversity and distribution of the cosmopolitan species Pseudo-nitzschia pungens (Bacillariophyceae): morphology, genetics, and ecophysiology of the three clades. J. Phycol. 51, 159-172.

Klein, C., Claquin, P., Bouchart, V., Le Roy, B., Véron, B., 2010. Dynamics of Pseudonitzschia spp. and domoic acid production in a macrotidal ecosystem of the Eastern
English Channel (Normandy, France). Harmful Algae 9 (2), 218-226.

Krock, B., Tillmann, U., John, U., Cembella, A.D., 2008. LC-MS/MS on board ship tandem mass spectrometry in the search for phycotoxins and novel toxigenic plankton from the North Sea. Anal. Bioanal. Chem. 392, 797-803.

Leandro, L.F., Teegarden, G.J., Roth, P.B., Wang, Z., Doucette, G.J., 2010. The copepod Calanus finmarchicus: a potential vector for trophic transfer of the marine algal biotoxin, domoic acid. J. Exp. Mar. Biol. Ecol. 382 (2), 88-95.

Lefebvre, K.A., Robertson, A., 2010. Domoic acid and human exposure risks: a review. Toxicon 56 (2), 218-230.

Lelong, A., Hégaret, H., Soudant, P., Bates, S.S., 2012. Pseudo-nitzschia (Bacillariophyceae) species, domoic acid and amnesic shellfish poisoning: revisiting previous paradigms. Phycologia 51, 168-216.

Lema, K.A., Latimier, M., Nézan, É., Fauchot, J., Le Gac, M., 2017. Inter and intra-specific growth and domoic acid production in relation to nutrient ratios and concentrations in Pseudo-nitzschia: phosphate an important factor. Harmful Algae 64, 11-19.

Liefer, J.D., Robertson, A., MacIntyre, H.L., Smith, W.L., Dorsey, C.P., 2013. Characterization of a toxic Pseudo-nitzschia spp. bloom in the Northern Gulf of Mexico associated with domoic acid accumulation in fish. Harmful Algae 26, 20-32.

Likumahua, S., 2013. The recent bloom of Pyrodinium bahamense var. compressum in Ambon Bay, Eastern Indonesia. Mar. Res. Indonesia 38 (1), 31-37.

Lim, H.C., Lim, P.T., Teng, S.T., Bates, S.S., Leaw, C.P., 2014. Genetic structure of Pseudonitzschia pungens (Bacillariophyceae) populations: implications of a global diversification of the diatom. Harmful Algae 37, 142-152. https://doi.org/10.1016/j.hal. 2014.06.004.

Ljubešić, Z., Bosak, S., Viličić, D., Borojević, K.K., Marić, D., Godrijan, J., Ujević, I., Peharec, P., Đakovac, T., 2011. Ecology and taxonomy of potentially toxic Pseudonitzschia species in Lim Bay (north-eastern Adriatic Sea). Harmful Algae 10 (6), $713-722$.

Macintyre, H.L., Stutes, A.L., Smith, W.L., Dorsey, C.P., Abraham, A., Dickey, R.W., 2011. Environmental correlates of community composition and toxicity during a bloom of Pseudo-nitzschia spp. in the northern Gulf of Mexico. J. Plankton Res. 33, 273-295.

Mafra Jr, L.L., Bricelj, V.M., Fennel, K., 2010. Domoic acid uptake and elimination kinetics in oysters and mussels in relation to body size and anatomical distribution of toxin. Aquat. Toxicol. 100 (1), 17-29.

Marić, D., Ljubešić, Z., Godrijan, J., Viličić, D., Ujević, I., Precali, R., 2011. Blooms of the potentially toxic diatom Pseudo-nitzschia calliantha Lundholm, Moestrup \& Hasle in coastal waters of the northern Adriatic Sea (Croatia). Estuar. Coast. Shelf S. 92 (3), 323-331.

Martin-Jézéquel, V., Calu, G., Candela, L., Amzil, Z., Jauffrais, T., Séchet, V., Weigel, P., 2015. Effects of organic and inorganic nitrogen on the growth and production of domoic acid by Pseudo-nitzschia multiseries and P. australis (Bacillariophyceae) in culture. Mar. Drugs 13 (12), 7067-7086.

McLaughlin, K., Nezlin, N., Howard, M.D.A., Beck, C.D.A., Kudela, R.M., Mengel, M.J., Robertson, G., 2017. Rapid nitrification of wastewater ammonium near coastal ocean outfalls, Southern California, USA. Estuar. Coast. Shelf S. 186, 263-275.

Naz, T., Burhan, Z., Munir, S., Siddiqui, P.J.A., 2012. Taxonomy and seasonal distribution of Pseudo-nitzschia species (Bacillariophyceae) from the coastal waters of Pakistan. Pak. J. Bot. 44 (4), 1467-1473.

Pan, Y., Parsons, M.L., Busman, M., Moeller, P.D., Dortch, Q., Powell, C.L., Doucette, G.J., 2001. Pseudo-nitzschiasp. cf.pseudodelicatissima - a confirmed producer of DA from the northern Gulf of Mexico. Mar. Ecol. Prog. Ser. 220, 83-92.

Parsons, M.L., Dortch, Q., Doucette, G.J., 2013. An assessment of Pseudo-nitzschia population dynamics and domoic acid production in coastal Louisiana. Harmful Algae 30, 65-77.

Pello, F.S., Adiwilaga, E.M., Huliselan, N.V., Damar, A., 2014. Pengaruh musim terhadap beban masukan nutrien di Teluk Ambon Dalam. J. Bumi Lestari 14 (1), 63-73 (in Indonesian, with English abstract).

Rue, E., Bruland, K., 2001. Domoic acid binds iron and copper: a possible role for the toxin produced by the marine diatom Pseudo-nitzschia. Mar. Chem. 76 (1-2), 127-134.

Sahraoui, I., Grami, B., Bates, S.S., Bouchouicha, D., Chikhaoui, M.A., Mabrouk, H.H., Hlaili, A.S., 2012. Response of potentially toxic Pseudo-nitzschia (Bacillariophyceae) populations and domoic acid to environmental conditions in a eutrophied, SW Mediterranean coastal lagoon (Tunisia). Estuar. Coast. Shelf S. 102, 95-104.

Saputra, F.R.T., Lekalette, J.D., 2016. Dinamika masa air di Teluk Ambon. Widyariset 2 (2), 143-152 (in Indonesian, with English abstract).

Schnetzer, A., Miller, P.E., Schaffner, R.A., Stauffer, B.A., Jones, B.H., Weisberg, S.B., DiGiacomo, P.M., Berelson, W.M., Caron, D.A., 2007. Blooms of Pseudo-nitzschia and domoic acid in the San Pedro Channel and Los Angeles harbor areas of the Southern California Bight, 2003-2004. Harmful Algae 6, 372-387.

Scholin, C.A., Gulland, F., Doucette, G.J., Benson, S., Busman, M., Chavez, F.P., Cordaro, J., DeLong, R., De Vogelaere, A., Harvey, J., Haulena, M., Lefebvre, K.A., Lipscomb, T., Loscutoff, S., Lowenstine, L.J., Marin, I.I.I.R., Miller, P.E., McLellan, W.A., Moeller, P.D.R., Powell, C.L., Rowles, T., Silvagni, P., Silver, M.W., Spraker, T., Trainer, V.L., Van Dolah, F.M., 2000. Mortality of sea lions along the central California coast linked to a toxic diatom bloom. Nature 403, 80-83.

Sekula-Wood, E., Benitez-Nelson, C., Morton, S., Anderson, C., Burrell, C., Thunell, R., 2011. Pseudo-nitzschia and domoic acid fluxes in Santa Barbara Basin (CA) from 1993 to 2008. Harmful Algae 10 (6), 567-575.

Selander, E., Berglund, E.C., Engström, P., Berggren, F., Eklund, J., Harðardóttir, S., Lundholm, N., Grebner, W., Andersson, M.X., 2019. Copepods drive large-scale traitmediated effects in marine plankton. Sci. Advanc. 5 (2), eaat5096.

Sidharta, B.R., 2005. The current status of research on harmful algal bloom (HAB) in Indonesia. J. Coast. Dev. 6 (2), 73-85.

Sison-Mangus, M.P., Jiang, S., Tran, K.N., Kudela, R.M., 2014. Host-specific adaptation governs the interaction of the marine diatom, Pseudo-nitzschia and their microbiota. 
ISME J. 8 (1), 63.

Smith, J., Gellene, A.G., Hubbard, K.A., Bowers, H.A., Kudela, R.M., Hayashi, K., Caron, D.A., 2017. Pseudo-nitzschia species composition varies concurrently with domoic acid concentrations during two different bloom events in the Southern California Bight. J. Plankton Res. 40 (1), 29-45.

Somavilla, R., González-Pola, C., Fernández-Diaz, J., 2017. The warmer the ocean surface, the shallower the mixed layer. How much of this is true? J. Geophys. Res-Oceans 122 (9), 7698-7716.

Strickland, J.D., Parsons, T.R., 1972. A Practical Handbook of Seawater Analysis. The Alger press Ltd.

Tammilehto, A., Nielsen, T.G., Krock, B., Møller, E.F., Lundholm, N., 2015. Induction of domoic acid production in the toxic diatom Pseudo-nitzschia seriata by calanoid copepods. Aquat. Toxicol. 159, 52-61.

Tammilehto, A., Nielsen, T.G., Krock, B., Møller, E.F., Lundholm, N., 2012. Calanus spp.-vectors for the biotoxin, domoic acid, in the Arctic marine ecosystem? Harmful Algae 20, 165-174.

Tatters, A.O., Fu, F.-X., Hutchins, D.A., 2012. High CO2 and silicate limitation synergistically increase the toxicity of Pseudo-nitzschia fraudulenta. PLoS One 7 (2), e32116. https://doi.org/10.1371/journal.pone.0032116.

Teng, S.T., Leaw, C.P., Lim, H.C., Lim, P.T., 2013. The genus Pseudo-nitzschia (Bacillariophyceae) in Malaysia, including new records and a key to species inferred from morphology-based phylogeny. Botanica Marina 56 (4), 375-398.

Terseleer, N., Gypens, N., Lancelot, C., 2013. Factors controlling the production of domoic acid by Pseudo-nitzschia (Bacillariophyceae): a model study. Harmful Algae 24, 45-53.

Thessen, A.E., Bowers, H.A., Stoecker, D.K., 2009. Intra-and interspecies differences in growth and toxicity of Pseudo-nitzschia while using different nitrogen sources. Harmful Algae 8 (5), 792-810.

Thoha, H., Adnan, Q., Sidabutar, T., Sugestiningsih, 2007. Note on the occurrence of phytoplankton and its relation with mass mortality in the Jakarta Bay, May and November 2004. Makara Sains 11 (2), 63-67.

Thorel, M., Claquin, P., Schapira, M., Le Gendre, R., Riou, P., Goux, D., Le Roy, B., KientzBouchart, V., Fauchot, J., 2017. Nutrient ratios influence variability in Pseudo-nitzschia species diversity and particulate domoic acid production in the Bay of Seine (France). Harmful Algae 68, 192-205.

Thorel, M., Fauchot, J., Morelle, J., Raimbault, V., Le Roy, B., Miossec, C., KientzBouchart, V., Claquin, P., 2014. Interactive effects of irradiance and temperature on growth and domoic acid production of the toxic diatom Pseudo-nitzschia australis
(Bacillariophyceae). Harmful Algae 39, 232-241.

Trainer, V.L., Adams, N.G., Bill, B.D., Stehr, C.M., Wekell, J.C., Moeller, P.D.R., Busman, M., Woodruff, 2000. DA production near California coastal upwelling zones, June 1998. Limnol. Oceanogr. 45 (8), 1818-1833.

Trainer, V.L., Hickey, B.M., Horner, R.A., 2002. Biological and physical dynamics of domoic acid production off the Washington coast. Limnol. Oceanogr. 47 (5), 1438-1446.

Trainer, V.L., Bates, S.S., Lundholm, N., Thessen, A.E., Cochlan, W.P., Adams, N.G., Trick, C.G., 2012. Pseudo-nitzschia physiological ecology, phylogeny, toxicity, monitoring and impacts on ecosystem health. Harmful Algae 14, 271-300.

Trainer, V.L., Pitcher, G.C., Reguera, B., Smayda, T.J., 2010. The distribution and impacts of harmful algal bloom species in eastern boundary upwelling systems. Prog. Oceanogr. 85 (1-2), 33-52.

Umhau, B., Benitez-Nelson, C., Anderson, C., McCabe, K., Burrell, C., 2018. A time series of water column distributions and sinking particle flux of Pseudo-Nitzschia and domoic acid in the Santa Barbara Basin, California. Toxins 10 (11), 480.

Van Meerssche, E., Greenfield, D.I., Pinckney, J.L., 2018. Coastal eutrophication and freshening: Impacts on Pseudo-nitzschia abundance and domoic acid allelopathy. Estuar. Coast. Shelf S. 209, 70-79.

Vilas, L.G., Spyrakos, E., Palenzuela, J.M.T., Pazos, Y., 2014. Support Vector Machinebased method for predicting Pseudo-nitzschia spp. blooms in coastal waters (Galician rias, NW Spain). Prog. Oceanogr. 124, 66-77.

Wouthuyzen, S., Tan, C.K., Ishizaka, J., Son, T.P.H., Ransi, V., Tarigan, S., Sediadi, A. 2007. Monitoring of algal blooms and massive fish kill in the Jakarta Bay, Indonesia using satellite imageries. Proceedings of the First PI Joint Symposium of ALOS Data Node for ALOS Science Program in Kyoto, Japan 19-23.

Wyrtki, K., 1961. Physical Oceanography of the Southeast Asian Waters. California. .

Zabaglo, K., Chrapusta, E., Bober, B., Kaminski, A., Adamski, M., Bialczyk, J., 2016. Environmental roles and biological activity of domoic acid: a review. Algal Res. 13, 94-101.

Zhu, Z., Qu, P., Fu, F., Tennenbaum, N., Tatters, A.O., Hutchins, D.A., 2017. Understanding the blob bloom: Warming increases toxicity and abundance of the harmful bloom diatom Pseudo-nitzschia in California coastal waters. Harmful Algae 67, 36-43.

Zijlstra, J.J., Baars, M.A., Tijssen, S.B., Wetsteyn, F.J., Witte, J.I., Ilahude, A.G., 1990. Monsoonal effects on the hydrography of the upper waters $(<300 \mathrm{~m})$ of the eastern Banda Sea and northern Arafura Sea, with special reference to vertical transport processes. J. Sea Res. 25 (4), 431-447. 